\title{
Biology and Fertility of Soils
}

\section{Molecular techniques and classical and isotopic analyses reflect the short-term impacts of soybean management on ammonia oxidizers in a Brazilian savanna under restoration \\ --Manuscript Draft--}

\begin{tabular}{|c|c|}
\hline Manuscript Number: & BFSO-D-15-00573R2 \\
\hline Full Title: & $\begin{array}{l}\text { Molecular techniques and classical and isotopic analyses reflect the short-term impacts } \\
\text { of soybean management on ammonia oxidizers in a Brazilian savanna under } \\
\text { restoration }\end{array}$ \\
\hline Article Type: & Original Paper \\
\hline Keywords: & Ammonia oxidizers; amoA; Central Brazilian Savanna; Cerrado; Soybean \\
\hline Corresponding Author: & $\begin{array}{l}\text { Ricardo H. Krüger, PhD } \\
\text { Universidade de Brasilia } \\
\text { Brasilia, DF BRAZIL }\end{array}$ \\
\hline \multicolumn{2}{|l|}{$\begin{array}{l}\text { Corresponding Author Secondary } \\
\text { Information: }\end{array}$} \\
\hline Corresponding Author's Institution: & Universidade de Brasilia \\
\hline \multicolumn{2}{|l|}{$\begin{array}{l}\text { Corresponding Author's Secondary } \\
\text { Institution: }\end{array}$} \\
\hline First Author: & Elisa C. P. Catão, M.D. \\
\hline \multicolumn{2}{|l|}{ First Author Secondary Information: } \\
\hline \multirow[t]{6}{*}{ Order of Authors: } & Elisa C. P. Catão, M.D. \\
\hline & Fabyano A. C. Lopes, M.D. \\
\hline & Marciano R. Rubini, PhD \\
\hline & Gabriela B. Nardoto, PhD \\
\hline & Jim I. Prosser \\
\hline & Ricardo H. Krüger, PhD \\
\hline \multicolumn{2}{|c|}{ Order of Authors Secondary Information: } \\
\hline \multicolumn{2}{|l|}{ Funding Information: } \\
\hline Abstract: & $\begin{array}{l}\text { Interactions between soil characteristics and soil microbiota influence soil ecosystem } \\
\text { processes such as nitrification; however, their complexity makes interpretation difficult. } \\
\text { Furthermore, the impact of soil management systems on abundance and activity of soil } \\
\text { microbial community is poorly understood, especially in the Neotropics. To investigate } \\
\text { these interactions, the effects of tillage, inorganic fertilization, and plant cover on the } \\
\text { abundance of ammonia-oxidizing archaea (AOA) and ammonia-oxidizing bacteria } \\
\text { (AOB) were assessed by quantification of the marker gene (amoA) during different } \\
\text { stages of soybean cultivation in a site under restoration from gravel extraction in the } \\
\text { Central Brazilian Savanna (Cerrado). Results of molecular analysis and classic and } \\
\text { isotope techniques showed that levels of organic } \mathrm{C} \text { and NH4+-N were higher in the } \\
\text { soybean field during fallow than in an adjacent undisturbed field (Campo sujo). } \\
\text { Ammonia oxidizer abundance and nitrification rates were also higher in the agricultural } \\
\text { soil than in the undisturbed site, with the lowest ammonium:nitrate ratio in tilled soil. } \\
\text { Soil } \delta 15 N \text { was lower in the undisturbed soil than the agricultural soil. Both AOA and } \\
\text { AOB were more abundant during soybean crop transitional stages, and this increase } \\
\text { positively correlated with soil pH, particularly for AOB abundance, in tilled soil and } \\
\text { within the soybean rhizosphere. The results suggest that AOB have more copiotrophic } \\
\text { characteristics than AOA and are better able to change available ammonium in the soil. } \\
\text { The combination of standard soil ecological methods and modern molecular analysis } \\
\text { show the short-term modification of ammonia oxidizer abundance and soil N dynamics } \\
\text { in a managed system within the Cerrado biome. }\end{array}$ \\
\hline
\end{tabular}


Christine V Hawkes

Associate Professor, University of Texas at Austin

chawkes@austin.utexas.edu

Researcher with experience in the intersection of plant, microbial and ecosystem ecology.

leda de Carvalho Mendes

EMBRAPA

ieda.mendes@embrapa.br

Recognized researcher on soil from the Cerrado biome and its biogeochemical cycles of $\mathrm{C}$ and $\mathrm{N}$, with emphasis in the biological nitrogen fixation with soybean plants.

Jason Kaye

Pennsylvania State University College of Agricultural Sciences

jpk12@psu.edu

Researcher with expertise in carbon and nitrogen cycles in both native and managed soils. 


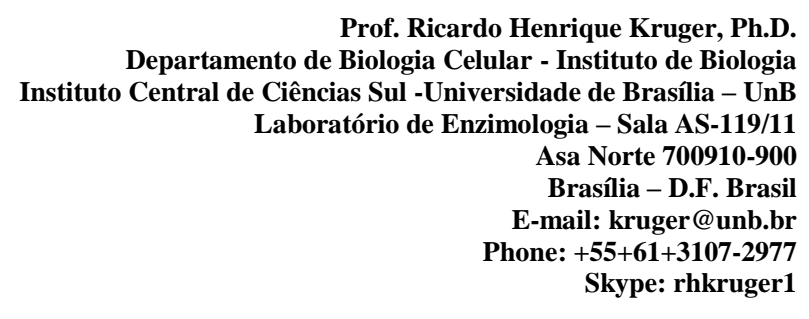

Brasília, December $18^{\text {th }}, 2015$

\section{Dear Editor Paolo Nannipieri}

Please accept this revised submission of the manuscript entitled "Molecular techniques and classical and isotopic analyses reflect the short-term impacts of soybean management on ammonia oxidizers in a Brazilian savanna under restoration" by Catão et al. as an original paper Biology and Fertility of Soils. The manuscript was modified according to editor's suggestions for minor corrections. The version with all accepted changes were uploaded. As well as the file with our responses to the reviewers' comments.

All authors have read the "Authors Instructions" and agree to this submission. We also state that the data presented is original and it neither is published or submitted for publication nor will be published, if accepted, elsewhere in any language without written consent of the copyright holder.

Conflict of interest statement: The authors declare no conflict of interest.

Sincerely,

Ricardo Krüger, $\mathrm{PhD}$. 
Ref.: Ms. No. BFSO-D-15-00573R1

Ecology and molecular techniques reflect the short-term impacts of soybean management on ammonia oxidizers in a Brazilian savanna under restoration

Biology and Fertility of Soils

Dear Dr. Krüger,

I have reviewed your manuscript titled "Ecology and molecular techniques reflect the short-term impacts of soybean management on ammonia oxidizers in a Brazilian savanna under restoration" and the manuscript is accepted for publication after revision according to the following comments:

General:

1) I suggest rewriting the title in the following way so as to better reflect the content: "Molecular techniques and classical and isotopic analyses reflect.in a savanna soil under".

Title was changed as suggested

Molecular technique, classical and isotopic analyses reflect the short-term impacts of soybean management on ammonia oxidizers in a Brazilian savanna under restoration

2) There are part of Results where you discuss data. These parts should be included in the Discussion section See lines 267-274, 316-318, 330-331.

Only the first set of lines was transferred to the Discussion section. The other two indicated extracts were already discussed and were just deleted from Results.

3) It is not scientifically correct to state "ammona quality and quantity" at line 405. I suggest "2008) presence of $\mathrm{NH} 3$ or $\mathrm{NH} 4+$ and $\mathrm{NH} 3$ or $\mathrm{NH} 4+$ concentration (".

We agree that the terminology was not correct. The sentence was changed to " $\mathrm{NH}_{3}$ and $\mathrm{NH}_{4}{ }^{+}$ concentration". We assumed that presence can be deduced from concentration.

4) lines 438-439, please explain better. Do you mean substances promoting AOB growth and activity? Or, substances inhibiting growth and activity of AOA? Which substances? Are there references?

We meant the release of $\mathrm{C}$ and $\mathrm{N}$ substrates and increase in their availability to the microbiota.

Sentence was changed.

Specific:

LIne 42, "systems on abundance and activity of microbial community is poorly".

Changed as suggested.

Line 52, "AOB abuance".

Abundance was added to the sentence "...particularly for AOB..."

Line 56 ,"soil ecoloical methods"

Changed as suggested.

PLease do not indent lines 62, Indent was deleted.

PLease substitute "nitrogen" with "N" at lines 72, 82, 83 86, 96, 101, 104 160, 167, 361, 368 (twice), 376, 378, 387, 396, 397, 399, 663.

Substituted as suggested. 
PLease substitute "carbon" with "C" at lines 82, 399, 402, 407.

Substituted as suggested.

LIne 74, please write "higher enzyme...microbal biomass C (".

Changed as suggested.

Line 90, "Pinto et al 2002, 2006)".

Changed as suggested.

Line 92, "Rangn et al 211)".

Did not understand the change. However, references were revised.

LIne 107, "Paula et al 2014"

Changed as suggested.

Line 174 "is a sandy".

Corrected.

LIne 177, "as a control".

Corrected.

LIne274, "Pinto et al 2002".

Corrected.

Line 283, "2A). Nitrogen immobilization".

Please write "net N mineralization" at lines 285, 290.

Changed as suggested

LIne 311, "abundances of AOA".

Changed as suggested

LInes 325-326,"by comparing rhizosphere".

Changed as suggested

LIne 346 ,"to assess abundances of both AOA".

Changed as suggested

LIne 365 "Both NH4+-N".

Changed as suggested

Lines 372-379, "Cruvinel et al (2011) reported...NO3--N; NH4+-N concentration in the soybean....mineral N. Cruvinel et al (2011) also discussed...between rows. Low".

Modified as suggested 
LInes 397-398,"fixation were low".

Corrected.

LIne 405, "Rangin et al 2011;".

Corrected.

LInes 414-415"Ranginet al 2010a, 211)".

Corrected.

Line 445, please add citation after "AOB".

We agreed that there was missing references in this sentence. However, when revising, the sentence did not add information to the discussion and it was then deleted.

Please abbreviate the name of the journal at lines 506, 510, 516-517, 523

Corrected.

PLease write "Microbiol" at lines 542, 551, 602.

Corrected.

PLease complete the list of authors at line 547.

Corrected.

Please write "Ecol" at lines 551, 570.

Corrected.

LInes 571, 572, "forms. In Sparks DL (Ed)...vol 3. Soil...America, Madison, WI, pp".

Corrected.

Line 574, "Pesquisa Agropecuaria Brasileira".

Corrected.

Line 587, please write in an abbreviated form the name of the journal.

Changed.

Line 590, "PLant Soil"

Corrected.

LIne598, add the abbreviate name of the journal.

Corrected.

Are the references at lines 608,610 cited in the text?

Reference 608 (Ribeiro and Walter) are cited in MM line 132. Rice was cited in line 238.

Line 655, "physicochemical properties based".

Changed. 
Along with your revised manuscript, you will need to supply a seperate file "author's response to the referees' comments" in which you list all the changes you have made to the manuscript and in which you detail your responses to all the comments passed by the referee(s). Should you disagree with any comment(s), please explain why. Please be sure to return the annotated copies of your manuscript.

Your revision is due by 10 January 2016.

To submit a revision, go to http://bfso.edmgr.com/ and log in as an Author. You will see a menu item call Submission Needing Revision. You will find your submission record there.

Please make sure to submit your editable source files (i. e. Word, TeX)

Yours sincerely

Paolo Nannipieri

Editor-in-Chief

Biology and Fertility of Soils 


\section{Click here to view linked References}

Molecular techniques and classical and isotopic analyses reflect the short-term impacts of soybean management on ammonia oxidizers in a Brazilian savanna under restoration

Catão, E.C.P. ${ }^{1}$; Lopes, F.A.C. ${ }^{1}$; Rubini, M. R. ${ }^{1}$; Nardoto, G. B. ${ }^{2}$; Prosser, J.I. ${ }^{3}$; Krüger, R.H. ${ }^{1}$

${ }^{1}$ Departamento de Biologia Celular, Instituto de Biologia, Universidade de Brasília -Campus Darcy Ribeiro, Brasília, Brazil, 700910-900

${ }^{2}$ Departamento de Ecologia, Instituto de Biologia, Universidade de Brasília -Campus Darcy Ribeiro, 70910-900, Brasília, Brazil, 700910-900

${ }^{3}$ Institute of Biological and Environmental Sciences, University of Aberdeen, Cruickshank Building, St. Machar Drive, Aberdeen AB24 3UU, UK

Corresponding author:

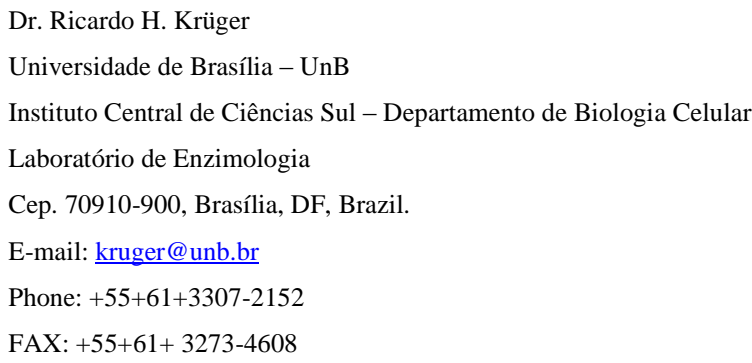

Running title: Short-term impact on ammonia oxidizers in Cerrado

Keywords: Ammonia oxidizers, amoA, nitrate, Central Brazilian Savanna, Cerrado, soybean

Acknowledgements: The authors are very grateful to Mr. Fabiano Bielefeld Nardotto, owner of the Tabapuã dos Pireneus farm, for allowing our free movement around the farm and collection of soil samples, as well as providing information about soybean cultivation. The authors also thank Dr. Plínio de Camargo, who performed the isotopic analysis in the CENA laboratory at the University of São Paulo (USP). This work was supported by grants from the National Council of Technological and Scientific Development (CNPq), Brazilian Federal Agency for Support and Evaluation of Graduate Education (CAPES), and Foundation for Research Support of Distrito Federal (FAP-DF). 


\section{Introduction}

The impact of land use on the functioning of soil microbiota has consequences for the processes governed by these organisms and consequently for the terrestrial ecological services that they provide (e.g. decomposition and nutrient cycling). Agriculture and managed pasture for cattle breeding have converted approximately $53 \%\left(117,870 \mathrm{~km}^{2}\right)$ of the Cerrado biome landscape in the last two decades (Beuchle et al. 2015), with increasing alterations in floristic composition and edaphic characteristics due to fertilization, liming, and crop monoculture itself. Changes in soil use and management likely modify the $\mathrm{C}$ and $\mathrm{N}$ dynamics in these areas, leading to changes in soil $\mathrm{C}$ and $\mathrm{N}$ stocks and increases in greenhouse gas emissions to the atmosphere (Carvalho 2009).

Soil management and monoculture crops are associated with a decrease in total and microbial nitregen $\underline{N}$, particularly in conventional tillage systems (Hernández-Hernández and López-Hernández 2002). In contrast, no-till management is associated with better soil quality and higher levels of enzyme activity (Peixoto et al. 2010) and microbial earbon-C biomass (Vinhal-Freitas et al. 2012). In addition, no-till farming appears to have fewer effects on the composition of microbial communities (Rachid 2013). Previous research has shown that the soybean plant influences the composition of the soil microbial community, with lower microbial diversity observed during plant development in soils under soybean cultivation (Bresolin et al. 2010).

In the Amazonian forest, land use change alters functional gene diversity and the composition and abundance of soil microbial communities, with differences in soil $\mathrm{pH}$ and organic matter content linked to differences in the composition of genes, including those associated with earbon- $\underline{\mathrm{C}}$ and nitrogen- $\underline{\mathrm{N}}$ cycles (Paula et al. 2014). For example, $15 \%$ to $30 \%$ of genes related to the nitrogencycle are modified by bioenergy crops (Zea mays and Miscanthus giganteus) (Mao et al. 2011), indicating that agriculture has an impact not only on microbial taxonomic composition but also on its potential ecological functions.

In view of the economic and ecological costs of fertilization and nitrogen- $\mathrm{N}$ losses, it is important to investigate nitrifiers in Cerrado soils to develop better soil management practices. Undisturbed Cerrado soils under native vegetation have low $\mathrm{pH}$ and a high $\mathrm{NH}_{4}{ }^{+}-\mathrm{N}: \mathrm{NO}_{3}{ }^{-}$ratio but very low nitrification rates (Nardoto and Bustamante 2003) and insignificant $\mathrm{N}_{2} \mathrm{O}$ emissions (Cruvinel et al. 2011; Pinto et al. 2006; 2002). These characteristics are often associated with a greater abundance of ammonia-oxidizing archaea (AOA) (Gubry-Rangin et al. 2011; Gubry-Rangin et al. 2010; Nicol et al. 2008), which appear to prefer ammonia generated from the mineralization of organic $\mathrm{N}$ and are the predominant ammonia oxidizers in acid soils (Levičnik-Höfferle et al. 2012; Prosser and Nicol 2012; Zhang et al. 2012). In contrast, ammonia-oxidizing bacteria (AOB) are more commonly associated with nitrification in soils with higher ammonia input (Jia and Conrad 2009); therefore, the addition of inorganic or organic nitrogen- $\mathrm{N}$ fertilizers may influence the relative abundance of AOA and AOB. 
The abundance of ammonia oxidizers, which perform the rate-limiting step of nitrification, can be estimated by amplification of the $a m o A$ gene, which encodes subunit A of ammonia monooxygenase. Investigation of nitrification in the Cerrado biome is of particular interest because this ecosystem is nitrogenN-limited (Bustamante et al. 2012), with low nitrate content (Bustamante et al. 2006; Nardoto and Bustamante 2003) and low rates of nitrification (Nardoto and Bustamante 2003). These characteristics are usually associated with a high litter level and soil C:N ratio, leading to low availability of nitregen $-\mathrm{N}$ and a higher rate of $\mathrm{N}$ immobilization than mineralization (Nardoto and Bustamante 2003).

Long-term land use is believed to modify the composition of soil microbial communities (Jangid et al. 2011; Paula et al. 2014), but few studies have described the short-term impacts (Lazcano et al. 2013). This study investigated the short-term effects of land use change, over 134 days, on ammonia oxidizers and tested the following hypotheses: 1) AOA are more abundant than AOB in undisturbed Campo sujo soil and in soybean site during the fallow period because of lower $\mathrm{pH}$ and provision of ammonium mainly by net $\mathrm{N}$ mineralization; 2) the relative abundance of AOB is greater in agricultural fertilized soil; and 3) the relative abundance of AOB increases during crop establishment due to the increase in $\mathrm{pH}$ and addition of inorganic fertilizers, which are associated with an increase in nitrate content and nitrification. To test these hypotheses, changes in archaeal and bacterial amoA gene abundance were determined by qPCR analysis in a soybean field and in soil from an adjacent undisturbed site (Campo sujo). This work describes short-term changes in the abundance of ammonia oxidizers in soil being restored after decades of gravel extraction in the Cerrado biome by evaluating the impact of soil management on microbial communities. 


\section{Materials and methods}

Study sites and soil characteristics

The field sites are located in the Cerrado biome within a commercial farm, Fazenda Tabapuã dos Pireneus, in the municipality of Cocalzinho de Goiás (Federal State of Goiás, Brazil). Average precipitation and temperature during sampling (134 days between the first and last days of sampling, October 13, 2012 and March 24, 2013, respectively), measured at the nearest meteorological center (approximately $30 \mathrm{~km}$ from the farm; Pirenopolis, GO, Station 83376, 1550'60"S 48 57'36"W), were $270 \mathrm{~mm}$ per month (Figure S1) and $24.8^{\circ} \mathrm{C}$ (range $19^{\circ} \mathrm{C}-32.5^{\circ} \mathrm{C}$ ) (Table S1). The climate in the Cerrado biome is tropical (Köppen Aw), and all soil samples were collected during the wet season (October to April), when $90 \%$ of the annual precipitation occurs.

This study focused on two sites: an undisturbed site dominated by grass and dispersed shrubs,

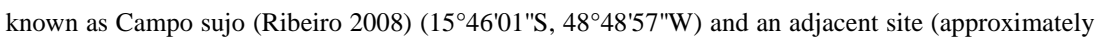
$200 \mathrm{~m}$ away) converted to soybean crop $\left(15^{\circ} 46^{\prime} 06^{\prime \prime S}, 48^{\circ} 48^{\prime} 55^{\prime \prime W}\right)$ (hereafter called the "soybean site"). Both sites have the same average altitude $(1118 \mathrm{~m})$, rainfall, and air temperature. The soybean site, which was degraded because of gravel removal activity that occurred over decades, is in the process of restoration to become an integrated livestock-forest system. It was first cultivated in 2012, with the establishment of maize followed by natural fallow. For maize cultivation a solution of $100 \mathrm{~kg}$ $\mathrm{ha}^{-1}$ of NPK (8:30:16) and $200 \mathrm{~kg} \mathrm{ha}^{-1}$ urea were applied to the soil after plowing. Soybean seeds were then sowed after a 1-year fallow period. For soybean cultivation, an NPK mixture (8:30:16) and 8\% micronutrient mixture (FPE BR12) were added to the soil at $5 \mathrm{~cm}$ depth. The transgenic soybean Glycine max Bayer variety 810 was sowed (after inoculation with rhizobia) every $10 \mathrm{~cm}$ in rows separated by $50 \mathrm{~cm}$. Soil from the soybean site was sampled four times: after 9 months of natural fallow since the last maize cultivation (F; mid-October 2013); the day after the soil was tilled to a depth of $20 \mathrm{~cm}$ (T; first week of December 2012); 1 month after fertilization (FE, first week of January 2013); and at the blossom soybean stage of development (end of February 2013), at which time bulk soil (B) and rhizosphere soil (soil in direct contact with the root) (Rz) were sampled. To obtain soil from the rhizosphere, plants near the bulk soil sampling location were removed, the soil loosely surrounding the plant was released, and adherent soil at the rhizosphere was collected mechanically in a plastic bag. Figure S2 illustrates the treatments and the two study sites. Although crops in this farm are usually cultivated using no-till management, the history of gravel extraction in the soybean site necessitated use of a plow in deeper soil $(20 \mathrm{~cm})$. The farmer did not initially consider plowing, and only the top $10 \mathrm{~cm}$ (more active layer) was sampled.

Soil was obtained at nine locations at the two adjacent sites. The nine replicates were used for $\mathrm{N}$ concentration, $\mathrm{pH}$, and soil water content measurements. However, for the remaining physicochemical data, molecular, and $\delta^{15} \mathrm{~N}$ analysis, the samples were combined into triplicate samples, according to the column numbers presented in Figure S2. In the soybean site, samples were taken from the rows. 
At each location, 10 soil core samples ( $10 \mathrm{~cm}$ deep, $5 \mathrm{~cm}$ diameter) (Figure S2) were obtained, passed through a 2-mm mesh sieve, combined, and then stored at $-20^{\circ} \mathrm{C}$ for subsequent physicochemical and molecular analyses. Inorganic nitrogen $-\underline{N}$ was extracted by agitating the soil sample for 1 hour in $1 \mathrm{M}$ $\mathrm{KCl}$ (1:5 soil:solution ratio). $\mathrm{NH}_{4}{ }^{+}-\mathrm{N}$ was determined using the Nessler colorimetric method (Embrapa 1999) with a spectrophotometer set at $425 \mathrm{~nm}$. $\mathrm{NO}_{3}{ }^{-} \mathrm{N}$ was determined by spectrophotometry (Mulvaney 1996) at $218 \mathrm{~nm}$, subtracting interference caused by organic matter at 254 and $280 \mathrm{~nm}$ (Meier 1991). These measurements were considered time zero and compared with $\mathrm{NH}_{4}{ }^{+}-\mathrm{N}$ and $\mathrm{NO}_{3}{ }^{-}-$ $\mathrm{N}$ measurements after samples were incubated in the laboratory in separate closed plastic bags for 7 days at room temperature in the dark (Piccolo et al. 1994). Net nitrogen- $\mathrm{N}$ mineralization and nitrification rates were expressed as changes in $\mathrm{NH}_{4}{ }^{+}-\mathrm{N}+\mathrm{NO}_{3}{ }^{-}-\mathrm{N}$ or $\mathrm{NO}_{3}{ }^{-}-\mathrm{N}$, respectively, during the 7 days of incubation. All results are expressed $\mathrm{g}^{-1}$ oven-dried $\left(105^{\circ} \mathrm{C}\right)$ soil.

Physicochemical and molecular analyses were performed in biological triplicates. Soil texture and concentrations of macro- and micronutrients were determined by using standard methods (Soils Embrapa-SNLCS) at SoloQuímica, Inc, Brasília, Brazil. Both soils are well-aerated and well-drained. The undisturbed Campo sujo soil is classified as sandy loam with $20.8 \%$ clay, and the soybean site is in a sandy clay soil with $31.7 \%$ clay. Both soils are considered to have a medium clay texture (Embrapa 2006) (Table 1). This work is not meant to compare the sites but to describe the rapid change in ammonia oxidizer abundance during the establishment of a soybean crop. The undisturbed site was used as a control to represent nitrification in a pristine Cerrado area.

\section{Isotope analysis}

All soil samples were air-dried and ground to a fine powder. A sub-sample of 15 to $20 \mathrm{mg}$ was sealed in a tin capsule and loaded into a ThermoQuest-Finnigan Delta Plus isotope ratio mass spectrometer (Finnigan-MAT; CA, USA) coupled with an elemental analyzer (Carlo Erba model 1110; Milan, Italy). These analyses were performed at Centro de Energia Nuclear na Agricultura (CENA - USP) in Piracicaba, Brazil. The natural abundance of stable isotopes of $\mathrm{C}$ and $\mathrm{N}$ were measured in relation to recognized international standards. As standard laboratory procedure, internal working standards (Atropine and soil standard no. 502-308 from LECO Corporation) were included in every run. Relative stable isotope values are reported in "delta" notation, as $\delta$ values in parts per thousand (\%o) according to the molar ratio $(\mathrm{R})$ of the rare to abundant isotope $\left({ }^{15} \mathrm{~N} /{ }^{14} \mathrm{~N} ;{ }^{13} \mathrm{C} /{ }^{12} \mathrm{C}\right)$, i.e. $\delta \%{ }_{0}=\left(\mathrm{R}_{\text {sample }} / \mathrm{R}_{\text {standard }}-\right.$ $1) \times 1000$. The precision of measurements was \pm 0.3 and $0.5 \%$ for $\delta^{13} \mathrm{C}$ and $\delta^{15} \mathrm{~N}$, respectively.

DNA extraction

DNA was extracted from $0.5 \mathrm{~g}$ soil using the FastDNA Spin Kit (MP Biomedicals) with additional treatment using solutions 2 and 3 from the PowerSoil DNA Isolation Kit (MO Bio Laboratories Inc.) to achieve maximum DNA yields with the least organic contamination. The DNA was analyzed by $1 \%$ 
(w/v) agarose gel electrophoresis. The average concentration of each 24 DNA sample (24 in total) was $100 \mathrm{ng} \mu \mathrm{L}^{-1}$ (Invitrogen Qubit fluorometer dsDNA BR Kit).

\section{Real-time PCR}

Thaumarchaeota 16S rRNA and archaeal and bacterial amoA genes were amplified in an Eppendorf Mastercycler and quantified using standard curves. Each 20- $\mu$ l reaction contained 1X QuantiFast master mix (for AOA) or QuantiTect master mix (for AOB) (Qiagen), $0.4 \mu \mathrm{M}$ primers (archaeal 16S rRNA, AOA $a m o A$ ) or $0.6 \mu \mathrm{M}$ primers (AOB $a m o A), 2 \mu \mathrm{g} \mu \mathrm{l}^{-1}$ bovine serum albumin (Promega), and 5 ng DNA. The thaumarchaeal 16S rRNA gene was amplified with the $771 \mathrm{f}$ and $958 \mathrm{r}$ primers (Ochsenreiter et al. 2003), the AOA amoA gene with the crenamo23f and crenamo616r primers (Tourna 2008), and the AOB amoA gene with the amoA1F and amoA2R primers (Rotthauwe et al. 1997). Cycling conditions were as follows: $15 \mathrm{~min}$ at $95^{\circ} \mathrm{C}$ followed by 40 cycles of $15 \mathrm{~s}$ at $94^{\circ} \mathrm{C}$ and $1 \mathrm{~min} 30 \mathrm{~s}$ at $60^{\circ} \mathrm{C}$ for the AOA amoA gene; and $15 \mathrm{~min}$ at $95^{\circ} \mathrm{C}$ followed by 45 cycles of $1 \mathrm{~min}$ at $94^{\circ} \mathrm{C}, 1 \mathrm{~min}$ at $55^{\circ} \mathrm{C}$, and $1 \mathrm{~min}$ at $72^{\circ} \mathrm{C}$ for the $\mathrm{AOB}$ amoA gene. Fluorescence was measured after $5 \mathrm{~s}$ at $80^{\circ} \mathrm{C}(\mathrm{AOA} a m o A)$ or $8 \mathrm{~s}$ at $83^{\circ} \mathrm{C}(\mathrm{AOB} a m o A)$ to exclude fluorescence contamination of potential primer-dimers. Melting curves between $65^{\circ} \mathrm{C}$ and $95^{\circ} \mathrm{C}$ were analyzed for each run.

Standards were made from 10-fold dilutions of the fragment of the gene of interest. This fragment was obtained by amplification of the genes with the respective primers from a composite of the soil samples used in this work. The fragment was cloned into a pGEM®-T Easy Vector (Promega) and re-amplified using M13 primers that recognize sites flanking the cloned fragment. Three clones of each gene were selected and verified by Sanger sequencing. The longer and more accurate sequence was chosen as the standard. Plasmid DNA concentrations were verified using a Qubit 2.0 fluorometer (Life Technologies) and NanoDrop 1000 spectrophotometer (Thermo Scientific). To verify the correct size of individual PCR products, melting curve and agarose gel electrophoresis analyses were performed. To exclude the fluorescence from potential primer-dimers, fluorescence was captured after each amplification cycle above $80^{\circ} \mathrm{C}$. Efficiency of amplification and $r^{2}$ values were 0.86 and 0.990 for archaeal 16S rRNA, 0.92 and 0.995 for archaeal amoA, and 0.86 and 0.994 for bacterial amoA, respectively. No inhibition was detected in assays consisting of soil DNA diluted in water or with a known amount of standard DNA.

\section{Statistical Analysis}

Statistical analyses were performed in R (v 3.0.2), and all qPCR and physicochemical data were analyzed for normality and homoscedasticity with both Kolmogorov-Smirnov and Levene's test statistics. Data that did not follow a normal distribution were log-transformed. One-way ANOVA tests were used to make multiple comparisons, with Tukey-Kramer post hoc tests to compare the group means shown in the graphs with different letters and corresponding colors. All graphs in the boxplot 
format were prepared in $\mathrm{R}$ with the ggplot 2 library, in which the default is to present the upper and lower sides of the box as the first and third quartile, whiskers corresponding to the highest and lowest values within 1.5 interquartile range (IQR), and dots representing outliers outside the IQR. The Pearson correlation was used to evaluate relationships between $\mathrm{qPCR}$ data and physiochemical variables with relevant biological implications (i.e., $\mathrm{pH}$, net nitrification rate, $\delta^{15} \mathrm{~N}$ ). The Bonferroni (Rice 1989) or Benjamini-Hochberg (BH) (Benjamini and Hochberg 1995) methods were used to correct $p$-values for multiple comparisons; the Bonferroni correction is more conservative. 


\section{Results}

Description of study sites and soil physicochemical characteristics

Water content of the undisturbed soil was lower than that of the soybean site at all time points, including soil collected on the same day in the soybean site during fallow. This finding may reflect differences in soil texture (Figure S1). Fallow soil from the soybean site contained residual material from the previous maize cultivation. Before sowing, 2 ton ha ${ }^{-1}$ limestone was applied to the soil, which increased soil $\mathrm{pH}$ in $\mathrm{H}_{2} \mathrm{O}$ from 5.5 (4.3 in $\mathrm{KCl}$ ) to 6 (5.2 in $\mathrm{KCl}$ ). The undisturbed Campo sujo soil had lower $\mathrm{pH}$ values (5.4 in $\mathrm{H}_{2} \mathrm{O}$ and 3.6 in $\mathrm{KCl}$ ) (Table $\mathrm{S} 1$ ).

Principal component analysis of soil physicochemical data (Figure 1) indicated that the physicochemical characteristics in the fallow soil differed significantly from soil collected in the soybean site at the other time points (Figure 1A). The undisturbed soil also differed from the fallow soil from the soybean site, which had higher organic $\mathrm{C}$ and $\mathrm{NH}_{4}{ }^{+}-\mathrm{N}$ concentrations (Figure 1B). However, other soils obtained from the soybean site clustered together, indicating similar physicochemical characteristics. In particular, these soils had higher $\mathrm{pH}$ and levels of nitrate, water, and micronutrients compared to the undisturbed Campo sujo soil and fallow soil (Figure 1B).

Ammonium and nitrate concentrations and soil $\delta^{15} \mathrm{~N}$

$\mathrm{NH}_{4}{ }^{+}-\mathrm{N}$ concentration in the undisturbed Campo sujo soil generally ranged from 5 to $8.3 \mu \mathrm{g} \mathrm{g}^{-1}$ dry soil, with two outliers of 11.8 and $48.7 \mu \mathrm{g} \mathrm{g}^{-1}$ dry soil (Figure $2 \mathrm{~A}$ ). The potential net $\mathrm{N}$ mineralization rate, determined by incubation of soil in the laboratory at room temperature, indicated that $\mathrm{NH}_{4}{ }^{+}-\mathrm{N}$ was becoming available in these soils at a rate of 0.8 to $3.29 \mathrm{NH}_{4}{ }^{+}-{\mathrm{N} \mu \mathrm{g} \mathrm{g}^{-1} \text { dry soil day }}^{-1}$ (Figure 2C). The undisturbed soil had the highest net $\mathrm{N}$ mineralization rate (average of $2 \mu \mathrm{gg} \mathrm{NH}_{4}{ }^{+} \mathrm{N} \mathrm{g}^{+}$dery soil day ${ }^{-1}$ ) and the lowest net nitrification rate, suggesting the inhibition of nitrification or low abundance

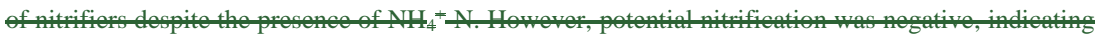

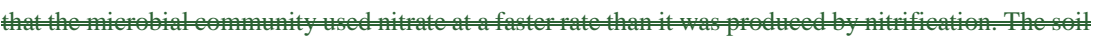

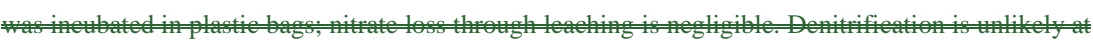
the moisture content of the soil used, and previous studies report that the los of Ngases is undectable in undistubed Cerrado soils (Bustamante et al. 2006; Pinto 2002).

$\mathrm{NH}_{4}{ }^{+}-\mathrm{N}$ concentration was higher than $\mathrm{NO}_{3}{ }^{-}-\mathrm{N}$ concentration in every soil sample but was particularly high in the undisturbed Campo sujo soil (Figure 2E). Fallow, tilled, and fertilized soils of the soybean site had similar average $\mathrm{NO}_{3}{ }^{-}-\mathrm{N}$ concentrations, which were higher than that of the bulk soil and rhizosphere soil collected during the blossom stage (Figure 2B). Nitrification was greater in fallow soil from the soybean site than in undisturbed Campo sujo soil (Figure 2D). Analysis of the soybean site samples showed a decrease in $\mathrm{NH}_{4}{ }^{+}-\mathrm{N}$ concentration as the crop developed, with significantly lower concentration in tilled soil and soil collected during the blossom stage of soybean development (both bulk and rhizosphere soils) than in fallow soil (Figure 2A). Nitrogen 
immobilization was greater than mineralization in fallow soil, recently tilled soil, bulk soil during the blossom stage, and especially in soil collected 1 month after fertilization. Nonetheless, the average net $\underline{N}$ mineralization differed significantly only between fertilized soil and soil collected during the blossom stage (both bulk and rhizosphere soils) (Figure 2C). Because fertilization was carried out at the same time as sowing, plant growth may have influenced the results obtained from soil collected 1 month after fertilization through $\mathrm{NH}_{4}{ }^{+}-\mathrm{N}$ uptake and the low inorganic $\mathrm{N}$ content in soil collected during the blossom stage. However, net $\mathrm{N}$ mineralization and nitrification occurred in a plant-free soil bag under laboratory conditions; therefore, $\mathrm{NH}_{4}{ }^{+}$would have been assimilated by microorganisms or oxidized to $\mathrm{NO}_{3}^{-}$by nitrifiers.

Another informative parameter was the $\mathrm{NH}_{4}{ }^{+}-\mathrm{N}: \mathrm{NO}_{3}{ }^{-}-\mathrm{N}$ ratio, with the lowest ratio observed in tilled soil, emphasizing the need for mineral $\mathrm{N}$ by the plants and soil microbial community during the blossom stage (Figure 2E). Figure 2E also shows the high ammonium:nitrate ratio in the undisturbed Campo sujo soil.

These results were supported by the integrated stable isotope ratios of $\mathrm{C}$ and $\mathrm{N}$ in these soils. The first soybean (C3 plant) cultivation did not change the $\delta^{13} \mathrm{C}$ signal that remained from maize (C4 plant) cultivation or from the grassland before agriculture installation (Figure S3); however, the integrated soil $\delta^{15} \mathrm{~N}$ values were more labile. Soil $\delta^{15} \mathrm{~N}$ was significantly lower in the undisturbed Campo sujo soil than in fallow soil from the soybean site (Figure $2 \mathrm{~F}$ ). Although soil $\delta^{15} \mathrm{~N}$ did not significantly change during the soybean cultivation period, an increase was observed during the blossom stage ( $p$-value 0.0795, results of ANOVA between samples from the soybean site) (Figure $2 \mathrm{~F})$. These integrated isotope values are congruent with instantaneous values for mineralization and nitrification obtained from each sample in which significant changes in $\mathrm{N}$ cycle dynamics were observed, compared to the adjacent undisturbed site.

Abundance of archaeal and bacterial amoA genes

Archaeal 16S rRNA and archaeal and bacterial amoA genes were amplified with specific primers to quantify the abundance of these genes in the undisturbed site and in the soybean site.

The mean abundances of $\mathrm{AOA}$ and $\mathrm{AOB}$ amoA genes in the undisturbed Campo sujo site were $3.4 \times 10^{5}$ and $1.6 \times 10^{3} \mathrm{~g}^{-1}$ dry soil, respectively, representing an average AOA:AOB ratio of 212.9 (Figure 3C). In addition, AOA and AOB were, respectively, 26-fold and 49-fold less abundant in the Campo sujo site than the soybean site during the fallow period (Figure 3). The thaumarchaeal $16 \mathrm{~S}$ rRNA:archaeal amoA gene ratio in the Campo sujo site varied from 785 to 1340 and was significantly higher than that of fallow soil from the soybean site. This result, which may be due to primer bias, indicates that not all archaea in the samples were ammonia oxidizers (Figure 3D).

The abundance of thaumarchaeal 16S rRNA and bacterial amoA increased during soybean development, but AOA amoA gene abundance decreased by $45 \%$ in the tilled soil compared to fallow 
soil. Tillage did not have the same effect on $\mathrm{AOB}$, as demonstrated by the lack of significant change in AOB amoA gene abundance between fallow and tilled soil samples (Figure 3B). In fertilized soil AOA amoA gene abundance increased 2.6-fold and AOB amoA abundance increased 2-fold (Figure 3). However, $\mathrm{AOB}$ amoA gene abundance was more affected by soybean cultivation than AOA amoA gene abundance, as demonstrated by comparing of -rhizosphere soil with bulk soil during the blossom stage of soybean development. Furthermore, the increase in AOB abundance from fallow soil to rhizosphere soil was 2.9 greater than the increase in AOA abundance.

Soybean cultivation affected the abundance of both bacterial and archaeal ammonia oxidizers. This finding may be explained by the increase in soil $\mathrm{pH}$ compared to the Campo sujo soil, which was one of the largest changes observed in the soil during soybean cultivation. The correlation between $\mathrm{pH}$ measured in $\mathrm{H}_{2} \mathrm{O}$ and $\log _{10}[\mathrm{AOB}]\left(\mathrm{R}^{2} 0.75\right.$, $p$-value $<0.05$ with the Bonferroni correction) was higher than the correlation between $\mathrm{pH}$ and $\log _{10}[\mathrm{AOA}]\left(\mathrm{R}^{2} 0.63, p\right.$-value $<0.05$ with the $\mathrm{BH}$ correction). Similarly, the pattern of $\delta^{15} \mathrm{~N}$ was more strongly associated with $\log _{10}[\mathrm{AOB}]\left(\mathrm{R}^{2} 0.96, p\right.$-value $<0.05$ corrected by Bonferroni method) than with $\log _{10}[\mathrm{AOA}]\left(\mathrm{R}^{2} 0.88, p\right.$-value $<0.05$ with the Bonferroni correction). Nevertheless, when analyzing only soils from the soybean site, AOA abundance did not correlate with $\mathrm{pH}$, and the correlation between $\mathrm{pH}$ and $\mathrm{AOB}$ abundance was lower $\left(\mathrm{R}^{2} 0.55, p\right.$ value $=0.72$ with the Bonferroni correction). Similarly, the correlation between $\delta^{15} \mathrm{~N}$ and $\log _{10}[\mathrm{AOA}]$ was not significant $\left(\mathrm{R}^{2} 0.24, p\right.$-value $=0.64$ corrected by $\mathrm{BH}$ method $)$ when analyzing only soils from the soybean site, but the correlation was still significant between $\delta^{15} \mathrm{~N}$ and $\log _{10}[\mathrm{AOB}]\left(\mathrm{R}^{2} 0.68, p\right.$ value $<0.05$ with the $\mathrm{BH}$ correction).

\section{Discussion}

In assessing links between environmental characteristics, nitrification, and the abundance of ammoniaoxidizer communities in the soil, it is important to assess abundances of both AOA and AOB, given the predominance of AOA amoA genes in many soils (Isobe 2012; Leininger 2006; Prosser and Nicol 2012). To assess the impact of land use conversion to soybean cultivation, ammonia oxidizer abundance and nitrification were evaluated in a soybean site after fallow, tillage, and fertilization and during the blossom stage of soybean development. These measurements were compared with those of an adjacent undisturbed Campo sujo site with low nitrate concentration, which is typical of Cerrado soil. These measurements support our hypothesis that both fertilization and soybean cultivation decrease the AOA:AOB ratio in association with increases in $\mathrm{pH}$ (Nicol et al. 2008; Prosser and Nicol 2012) and inorganic $\mathrm{NH}_{4}{ }^{+}$(Levičnik-Höfferle et al. 2012), which is consistent with studies reporting that AOA are predominant in low-nutrient, low-pH environments (Erguder et al. 2009; Prosser and Nicol 2012). However, this study highlights the rapidity of changes in nitrifiers, $\mathrm{N}$ dynamics, and yields that occur in Cerrado soils after conversion to soybean cultivation. 
The cultivation of soybeans in Brazil has been successfully implemented with inoculation of Bradyrhizobium strains to decrease or even completely eliminate the need for nitrogen $\underline{\underline{N}}$ fertilizers (Mendes et al. 2003). Nevertheless, the soybean site studied here required tillage and fertilization. Our results showed the effect of plant cover during the fallow period on soil recovery in the soybean site. Soil collected during the fallow period had soil characteristics similar to those of the undisturbed Campo sujo site, despite the different soil texture.

The undisturbed soil had the highest net $\mathrm{N}$ mineralization rate (average of $2 \mu \mathrm{g} \mathrm{NH} 4_{4}^{+}-\mathrm{N} \mathrm{g}^{-1}$ dry soil day ${ }^{-1}$ ) and the lowest net nitrification rate, suggesting the inhibition of nitrification or low abundance of nitrifiers despite the presence of $\mathrm{NH}_{4}{ }^{+}$-N. However, potential nitrification was negative, indicating that the microbial community used nitrate at a faster rate than it was produced by nitrification. The soil was incubated in plastic bags; nitrate loss through leaching is negligible. Denitrification is unlikely at the moisture content of the soil used, and previous studies report that the loss of $\mathrm{N}$ gases is undetectable in undisturbed Cerrado soils (Bustamante et al. 2006; Pinto et al. 2002).

Both $\mathrm{NH}_{4}{ }^{+}-\mathrm{N}$ and $\mathrm{NO}_{3}{ }^{-}-\mathrm{N}$ concentrations were particularly low in the soybean site during the blossom stage of soybean development, possibly because of $\mathrm{N}$ uptake by the soybean plants. $\mathrm{N}$ mineralization exceeded immobilization in the rhizosphere soil but not in the bulk soil, which suggests greater nitrogen $\underline{\mathrm{N}}$ availability due to symbiotic nitrogen $\underline{\mathrm{N}}$ fixation. The soil C:N ratio $>20$ (data not shown) in the bulk soil may partly explain the greater $\mathrm{N}$ immobilization, leading to depletion of $\mathrm{N}$ by both microbiota and plants.

The decrease in $\mathrm{NH}_{4}{ }^{+}-\mathrm{N}$ and $\mathrm{NO}_{3}{ }^{-}-\mathrm{N}$ during soybean growth was expected and is associated with periods of intense plant growth (Cruvinel et al. 2011). Nevertheless, Cruvinel et al. (2011) reported higher concentrations of $\mathrm{NO}_{3}{ }^{-} \mathrm{N}\left(1-52 \mathrm{mg} \mathrm{kg}^{-1}\right.$, depending on the period) and $\mathrm{NH}_{4}{ }^{+}-\mathrm{N}(21.3-$ $50.7 \mathrm{mg} \mathrm{NH}_{4}{ }^{+}-\mathrm{N} \mathrm{kg}^{-1}$ soil) in soils during soybean cultivation higher than the levels of $\mathrm{NO}_{3}{ }^{-}-\mathrm{N}$ and

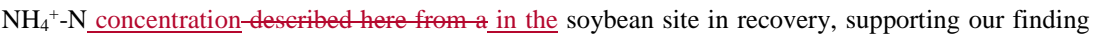
that the soils sampled in our study were relatively depleted in mineral nitrogen $\underline{N}$. Cruvinel et al. (2011)These researchers-also discussed possible competition between plant roots and microorganisms in the planted rows during cotton cultivation in the Cerrado because of the lower inorganic nitrogen $\underline{\mathrm{N}}$ availability and NO-N fluxes than that observed between rows-(Cruvinel 2011). Low abundance of $\mathrm{AOA}$ and $\mathrm{AOB}$ in Cerrado soils may be due to competition with soil fungi for ammonium or inhibition by bioactive compounds synthesized by fungi ( $Y u$ et al. 2014). Nardoto and Bustamante (2003) showed that in both burned and unburned Cerrado areas, inorganic nitrogen $\underline{N}$ content decreases during the rainy season, despite the observed increase in net $\mathrm{N}$ mineralization and net nitrification after the first rainfall events of the dry season (Nardoto and Bustamante 2003). These studies are consistent with our findings, as soils have higher levels of ammonia than nitrate, and the ammonium:nitrate ratio was lowest in the tilled soil, likely due to nitrogen $-\mathrm{N}$ release from organic matter. Similarly, the ammonium:nitrate ratio is high in integrated agricultural systems in Cerrado but is lower in crop- 
livestock and crop-livestock-forest systems compared to agroforestry and exotic pasture (Carvalho et al., personal communication). The same study also reports higher $\mathrm{N}_{2} \mathrm{O}$ emissions from all of these agricultural systems compared with native Cerrado soils, with crop-livestock having the highest levels (Carvalho et al., personal communication).

Despite lower soil nitrate concentrations than those reported by other studies, $\mathrm{N}$ losses from the soybean site compared with the undisturbed Campo sujo site are suggested by higher $\delta^{15} \mathrm{~N}$ values and greater nitrate accumulation in the managed system. The integrative soil $\delta^{15} \mathrm{~N}$ signal, which provides historical information on soil nitrogen- $\mathrm{N}$ dynamics, indicates that soybean cultivation affects soil $\mathrm{N}$ accumulation, as the expected values for symbiotic nitrogen $\mathrm{N}$ fixation are $\underline{\text { were lower, at } 0-}$ 2\%o (Delwiche et al. 1979). Nonetheless, the results demonstrate the labile characteristics of nitrogen $\underline{\mathrm{N}}$ compared to earbenC, as $\delta^{15} \mathrm{~N}$ tended to increase during soybean cultivation, changing the shortterm $\mathrm{N}$ dynamics in the cultivated soil, whereas no significant changes in $\delta^{13} \mathrm{C}$ were observed. A recent study reported that the $\delta^{15} \mathrm{~N}$ signature reflects a strong pattern of change according to land use, mainly due to soil earben-C dynamics and clay content (Craine JME 2015).

Many soil characteristics are associated with changes in soil nitrification, including $\mathrm{pH}$ (Gubry-Rangin et al. 2011; Nicol et al. 2008), $\mathrm{NH}_{3}$ and $\mathrm{NH}_{4}{ }^{+}$concentration ammonia quality and quantity (Levičnik-Höfferle et al. 2012; Stopnisek 2010), $\mathrm{O}_{2}$ (Erguder et al. 2009), temperature (Tourna 2008), soil moisture (Placella and Firestone 2013; Thion and Prosser 2014), and organic earben- $\underline{\mathrm{C}}$ (Erguder et al. 2009); however, $\mathrm{pH}$ and ammonia concentration have received greatest attention as potential drivers of ammonia oxidizer communities (Prosser and Nicol 2012). Kinetic studies of ammonia oxidation by Nitrosopumilus maritimus suggest that AOA have a higher affinity for ammonia (Martens-Habbena et al. 2009), but AOA may also be more sensitive than AOB to inhibition by high ammonia concentration (Prosser and Nicol 2012). In terms of $\mathrm{pH}$, there is strong evidence for the selection of AOA, rather than AOB, in acid soils (Gubry-Rangin et al. 2011; Nicol et al. 2008; Zhang et al. 2012). However, AOA also contribute to nitrification in soils with $\mathrm{pH}>5.5$ (Gubry-Rangin et al. 2011; Gubry-Rangin et al. 2010), and there is evidence for long-term pH selection of both AOB and AOA phylotypes in soil (Nicol et al. 2008; Stephen et al. 1998). The increased pH observed during soybean cultivation was associated with a lower AOA:AOB ratio in our study, but no significant effect on nitrification was detected, and the expected decrease in $\mathrm{pH}$ that frequently accompanies nitrification was not observed. This may be due to liming or the low rates of ammonia oxidation observed in these soils. Therefore, $\mathrm{pH}$ may limit ammonia oxidizer growth in these low-nitrate Cerrado soils.

In this study we observed that tillage, fertilization, liming, and soybean monoculture altered soil $\mathrm{pH}$, moisture, and inorganic $\mathrm{N}$ contents, all of which can influence the abundance and diversity of microbial communities and their functional potential, thereby influencing the production of nitrate, nitrite, NO, and $\mathrm{N}_{2} \mathrm{O}$ (Mao et al. 2011). The change in land use had differential effects on the abundance of AOA and AOB communities, reinforcing the idea that these two microbial groups have distinct ecological

\begin{tabular}{|l|}
\hline Formatted: Subscript \\
\hline Formatted: Not Superscript/ Subscript \\
\hline Formatted: Superscript \\
\hline
\end{tabular}


niches associated with environmental variables. Specifically, samples from recently tilled soil and soil collected from the rhizosphere had smaller $\mathrm{AOA} A \mathrm{AOB}$ ratios, and $\mathrm{AOB}$ showed a greater response to changes occurring during soybean cultivation. The lower abundance of AOA in undisturbed soil can be also related to the higher thaumarchaeal $16 \mathrm{~S}$ rRNA:archaeal amoA ratio, which, in the absence of primer bias, indicates a great abundance of non-ammonia-oxidizing Thaumarchaeota (e.g., belonging to group 1.1c) (Weber et al. 2015).

A recent metagenomic study reported that Thaumarchaeota representatives were more abundant in no-till soils than in soils under conventional tillage (Souza 2013), possibly because of greater organic matter content or sensitivity to tillage. Although the AOA amoA gene was more abundant in all of our soil samples, the increase in AOB amoA abundance in tilled soil was greater. This finding may reflect the disruption of soil structure and release of $\mathrm{C}$ and $\mathrm{N}$ substrates previously not available to the microbiota.

Our results provided evidence for our hypothesis that both AOA and AOB abundance increase during soybean cultivation, with AOB increasing more than AOA, as predicted. Although AOA were more abundant, nitrification was better explained by the increase in AOB abundance, as predicted by the current view that $\mathrm{AOB}$ contribute more to ammonia oxidation than AOA in fertilized oxic soils at near-neutral pH. Wertz et al. (2012) reported an increase in AOB abundance with fertilizer application and nitrification in pine forests (Wertz et al. 2012), but more recent work suggests more dynamic ehanges in $A O A$ than $A O B$. Hower, AOB abundance was more highly correlated with potential nitrification (Meyer et al. 2014), indicating that other factors can influence ammonia oxidizer communities. Moreover, although AOA abundance is potentially stable during the cultivation of bioenergy crops (Zea mays and Miscanthus giganteus), AOA diversity decreases, and AOB abundance increases, with this differential response to fertilization by AOA and AOB observed even 2 years after the fertilization (Mao et al. 2011).

A similar increase in the abundance of AOB, rather than AOA, was reported for a fertilized maize crop (Mao et al. 2011), and Mendes et al. (2014) recently showed that soybean plants select for the rhizosphere a specific subset of the soil bulk microbial community, which appears to be related to growth promotion and nutrition (Mao et al. 2011; Mendes 2014). Further studies are required to elucidate the differential effect of soybean cultivation on AOA and AOB abundance to determine whether these differences are direct effects of the soybean plant or due to fertilization promoting the growth of AOB.

\section{Conclusions}

Our study showed a rapid turnover (less than 1 year) of microbial communities and soil chemical properties due to anthropogenic impact in Cerrado soils. Land use changes promote differential shortterm effects on nitrification rates and $\mathrm{AOA}$ and $\mathrm{AOB}$ abundance, suggesting that these groups have 
different physiological characteristics with respect to nutrient availability. Results of molecular data and soil ecological analyses are complementary and provide insights into the impact of soybean management on ammonia oxidizers in an area under restoration in the Cerrado biome. Our results confirm the dominance of AOA in soils collected at the field site in Cocalzinho de Goiás (GO). These results are consistent with the low $\mathrm{pH}$ and nitrification rates observed in Cerrado soils in general. We found that despite ammonium availability in the undisturbed Campo sujo soil, the abundance of ammonia oxidizers was low, as determined by amoA gene amplification. Nevertheless, soybean cultivation altered both $\mathrm{AOA}$ and $\mathrm{AOB}$ abundance, with the soybean plants, nitrification rate, and $\mathrm{pH}$ affecting AOB more than AOA. Although these changes were observed in a small area, they suggest processes that occur on a larger scale. 


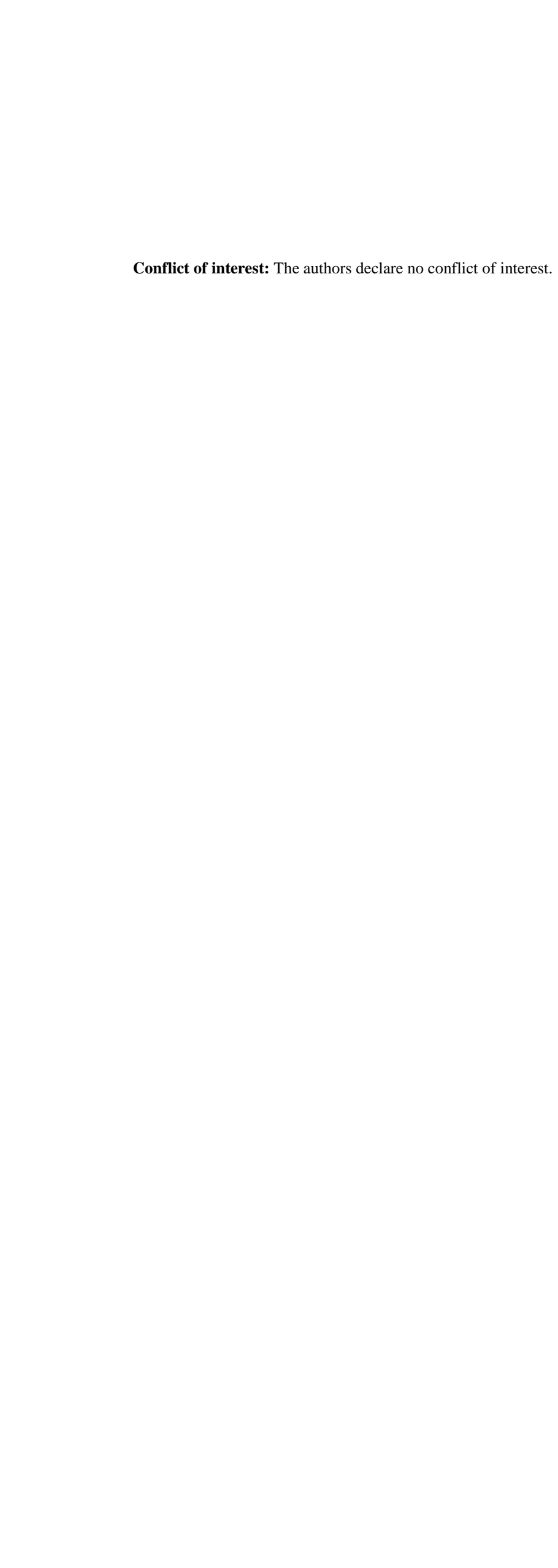




\section{References}

Benjamini Y, Hochberg Y (1995) Controlling the False Discovery Rate - a Practical and Powerful Approach to Multiple Testing J Roy Stat Soc B Met 57:289-300

Beuchle R, Grecchi RC, Shimabukuro YE, Seliger R (2015) Land cover changes in the Brazilian Cerrado and Caatinga biomes from 1990 to 2010 based on a systematic remote sensing sampling approach Appl Geogr 58:116-127

Bresolin JD, Bustamante MM, Kruger RH, Silva MR, Perez KS (2010) Structure and composition of bacterial and fungal community in soil under soybean monoculture in the Brazilian Cerrado Braz J Microbiol 41:391-403 doi:10.1590/S1517-838220100002000021

Bustamante MM, Nardoto GB, Pinto AS, Resende JC, Takahashi FS, Vieira LC (2012) Potential impacts of climate change on biogeochemical functioning of Cerrado ecosystems Braz J Biol 72:655-671 doi:10.1590/S1519-69842012000400005

Bustamante MMC, Medina E, Asner GP, Nardoto GB, Garcia-Montiel DC (2006) Nitrogen cycling in tropical and temperate savannas Biogeochemistry 79:209-237

Carvalho JLNC, J. L. N., Cerri, C. E. P., Feigl, B. J., Piccolo, M. C., Godinho, V. P., \& Cerri, C. C. (2009) Carbon sequestration in agricultural soils in the Cerrado region of the Brazilian Amazon Soil Till Res 103:342-349

Craine JME AJW, L.; Augusto, L.; Baisden, W. T.; Brookshire, E. N.; Cramer, M. D.; Hasselquist, N. J.; Hobbie, E. A.; Kahmen, A.; Koba, K.; Kranabetter, J. M.; Mack, M. C.; Marin-Spiotta, E.; Mayor, J. R.; McLauchlan, K. K.; Michelsen, A.; Nardoto, G. B.; Oliveira, R. S.; Perakis, S. S.; Peri, P. L.; Quesada, C. A.; Richter, A.; Schipper, L. A.; Stevenson, B. A.; Turner, B. 
L.; Viani, R. A.; Wanek, W.; Zeller, B. (2015) Convergence of soil nitrogen isotopes across global climate gradients Sci Rep 5:8280 doi:10.1038/srepo8280

Cruvinel ÊBF, Bustamante MMC, Kozovits ARK, Zepp RG (2011) Soil emissions of NO, N2O and $\mathrm{CO} 2$ from croplands in the savanna region of central Brazil Agric Ecosyst Environ 144:2940 doi:10.1016/j.agee.2011.07.016

Delwiche CC, Zinke PJ, Johnson CM, Virginia RA (1979) Nitrogen isotope distribution as a presumptive indicator of nitrogen fixation Botanical Gazette doi:10.2307/2474205 Embrapa (1999) Manual de análises químicas de solos, plantas e fertilizantes. Embrapa, Brasília Embrapa (2006) Sistema brasileiro de classificação de solos. 2nd edn. Embrapa - SPI, Rio de Janeiro

Erguder TH, Boon N, Wittebolle L, Marzorati M, Verstraete W (2009) Environmental factors shaping the ecological niches of ammonia-oxidizing archaea FEMS microbiology reviews 33:855-869 doi:10.1111/j.1574-6976.2009.00179.x

Gubry-Rangin C et al. (2011) Niche specialization of terrestrial archaeal ammonia oxidizers PNAS 108:21206-21211 doi:10.1073/pnas.1109000108

Gubry-Rangin C, Nicol GW, Prosser JI (2010) Archaea rather than bacteria control nitrification in two agricultural acidic soils FEMS Microbiol Ecol 74:566-574 doi:10.1111/j.15746941.2010.00971.x

Hammer O, Harper DAT, Ryan PD (2001) PAST: Paleontological Statistics software package for education and data analysis Palaeontologica Eletronica 4:9

Hernández-Hernández RM, López-Hernández D (2002) Microbial biomass, mineral nitrogen and carbon content in savanna soil aggregates under conventional and no-tillage Soil Biol Biochem 34:1563-1570

Isobe KK, K.; Suwa, Y.; Ikutani, J.; Fang, Y.; Yoh, M.; Mo, J.; Otsuka, S.; Senoo, K. (2012) High abundance of ammonia-oxidizing archaea in acidified subtropical forest soils in southern China after long-term N deposition FEMS Microbiol Ecol 80:193-203 doi:10.1111/j.1574-6941.2011.01294.x Jangid K, Williams MA, Franzluebbers AJ, Schmidt TM, Coleman DC, Whitman WB (2011) Landuse history has a stronger impact on soil microbial community composition than 
aboveground vegetation and soil properties Soil Biol Biochem 43

doi:10.1016/j.soilbio.2011.06.022

Jia Z, Conrad R (2009) Bacteria rather than Archaea dominate microbial ammonia oxidation in an agricultural soil Environ Microbiol 11:1658-1671 doi:10.1111/j.1462-2920.2009.01891.x

Lazcano C, Gómez-Brandón M, Revilla P, Domínguez J (2013) Short-term effects of organic and inorganic fertilizers on soil microbial community structure and function Biol Fert Soils 49:723-733

Leininger SU, T.; Schloter, M.; Schwark, L.; Qi, J.; Nicol, G.; Prosser, J.; Schuster, S.; Schleper, C. (2006) Archaea predominate among ammonia-oxidizing prokaryotes in soils Nature 442:806-809 doi:10.1038/nature04983

Levičnik-Höfferle S, Nicol GW, Ausec L, Mandić-Mulec I, Prosser JI (2012) Stimulation of thaumarchaeal ammonia oxidation by ammonia derived from organic nitrogen but not added inorganic nitrogen FEMS Microbiol Ecol 80:114-123 doi:10.1111/j.1574-

$6941.2011 .01275 . x$

Mao Y, Yannarell AC, Mackie RI (2011) Changes in $\mathrm{N}$-transforming archaea and bacteria in soil during the establishment of bioenergy crops PLoS One 6:e24750 doi:10.1371/journal.pone.0024750

Martens-Habbena W, Berube PM, Urakawa H, de la Torre JR, Stahl DA (2009) Ammonia oxidation kinetics determine niche separation of nitrifying Archaea and Bacteria Nature 461:976-979 doi:10.1038/natureo8465

Meier M (1991) Nitratbestimmung in Boden-Proben (N-min-Methode) LaborPraxis, Würzburg: 244-247

Mendes IC, Hungria M, Vargas MAT (2003) Soybean response to starter nitrogen and Bradyrhizobium inoculation on a Cerrado Oxisol under no-tillage and conventional 
tillage systems Revista Brasileira de Ciência do Solo 27:81-87 doi:10.1590/S010006832003000100009

Mendes LWK, E. E.; Navarrete, A. A. ; van Veen, J. A.; Tsai, S. M. (2014) Taxonomical and functional microbial community selection in soybean rhizosphere The ISME Journal 8:1577-1587 doi:10.1038/ismej.2014.17

Meyer A, Focks A, Radl V, Welzl G, Schöning I, Schloter M (2014) Influence of land use intensity on the diversity of ammonia oxidizing bacteria and archaea in soils from grassland ecosystems Microbial Ecol 67:161-166 doi:10.1007/s00248-013-0310-4

Mulvaney RL (1996) Nitrogen inorganic forms. In: Sparks DL (ed) Methods of soil analyses, vol 3. Soil Science Society of America, Madison, pp 1123-1184

Nardoto GB, Bustamante MMC (2003) Effects of fire on soil nitrogen dynamics and microbial biomass in savannas of Central Brazil Pesquisa Agropecuária Brasileira 38:955-962

Nicol GW, Leininger S, Schleper C, Prosser JI (2008) The influence of soil pH on the diversity, abundance and transcriptional activity of ammonia oxidizing archaea and bacteria Environ Microbiol 10:2966-2978 doi:10.1111/j.1462-2920.2008.01701.x

Ochsenreiter T, Selezi D, Quaiser A, Bonch-Osmolovskaya L, Schleper C (2003) Diversity and abundance of Crenarchaeota in terrestrial habitats studied by 16S RNA surveys and real time PCR Environ Microbiol 5:787-797

Paula FR, JL; Zhou, J; Wu, L; Mueller, RC; Mirza, BS; Bohannan, BJ; Nusslein, K; Deng, Y; Tiedje, JM; Pellizari, VH (2014) Land use change alters functional gene diversity, composition and abundance in Amazon forest soil microbial communities Mol Ecol 23:2988-2999 doi:10.1111/mec.12786

Peixoto RS, Chaer GM, Franco N, Reis Junior FB, Mendes IC, Rosado AS (2010) A decade of land use contributes to changes in the chemistry, biochemistry and bacterial community 
structures of soils in the Cerrado Antonie Van Leeuwenhoek 98:403-413 doi:10.1007/s10482-010-9454-0

Piccolo MC, Neill C, Cerri CC (1994) Net nitrogen mineralization and net nitrification along a tropical forest-to-pasture chronosequence Plant Soil 162:61-70 doi:10.1007/BF01416090

Pinto AS, Bustamante MMC, Kisselle K, Burke R, Zepp R, Viana LT, Varella RFM, M. (2002) Soil emissions of $\mathrm{N} 2 \mathrm{O}, \mathrm{NO}$, and $\mathrm{CO} 2$ in Brazilian Savannas: Effects of vegetation type, seasonality, and prescribed fires J Geophys Res 107:1-9 doi:10.1029/2001JD000342

Pinto ASB, M.M.C.; da Silva, M. R. S. S.;Kisselle, K. W.;Brossard, M.;Kruger, R.;Zepp, R. G.;Burke, R. A. (2006) Effects of Different Treatments of Pasture Restoration on Soil Trace Gas Emissions in the Cerrados of Central Brazil Earth Interact 10:1-26

Placella SA, Firestone MK (2013) Transcriptional response of nitrifying communities to wetting of dry soil Appl Environ Microbiol 79:3294-3302 doi:10.1128/AEM.00404-13

Prosser J, Nicol G (2012) Archaeal and bacterial ammonia-oxidisers in soil: the quest for niche specialisation and differentiation Trends Microbiol 20:523-531 doi:10.1016/j.tim.2012.08.001

Rachid CTS, A. L.; Piccolo, M. C.; Balieiro, F. C.; Coutinho, H. L.; Peixoto, R. S.; Tiedje, J. M.; Rosado, A. S. (2013) Effect of sugarcane burning or green harvest methods on the Brazilian Cerrado soil bacterial community structure PLoS One 8:e59342 doi:10.1371/journal.pone.0059342

Ribeiro JFW, B.M.T. (2008) As principais fitofisionomias do Bioma Cerrado. In: Sano SMA, S.P.; Ribeiro, J.F. (ed) Cerrado: ecologia e flora. Embrapa Cerrados Planaltina, pp 151-212

Rice WR (1989) Analyzing Tables of Statistical Tests Evolution 43:223-225 doi:Doi $10.2307 / 2409177$

Rotthauwe JH, Witzel KP, Liesack W (1997) The ammonia monooxygenase structural gene amoA as a functional marker: molecular fine-scale analysis of natural ammonia-oxidizing populations Appl Environ Microbiol 63:4704-4712

Souza RCC, M.E.; Vasconcelos,A.T.R.; Nogueira, M.A.; Hungria,M. (2013) Soil metagenomics reveals differences under conventional and no-tillage with crop rotation or succession Appl Soil Ecol 72 doi:10.1016/j.apsoil.2013.05.021 Stephen JR, Kowalchuk GA, Bruns MAV, McCaig AE, Phillips CJ, Embley TM, Prosser JI (1998) Analysis of beta-subgroup proteobacterial ammonia oxidizer populations in soil by 
denaturing gradient gel electrophoresis analysis and hierarchical phylogenetic probing Appl Environ Microbiol 64:2958-2965

Stopnisek NG-R, C.; Hofferle, S.; Nicol, G. W.; Mandic-Mulec, I.; Prosser, J. I. (2010) Thaumarchaeal Ammonia Oxidation in an Acidic Forest Peat Soil Is Not Influenced by Ammonium Amendment Appl Environ Microbiol 76:7626-7634 doi:Doi 10.1128/Aem.00595-10

Thion C, Prosser JI (2014) Differential response of nonadapted ammonia-oxidising archaea and bacteria to drying-rewetting stress FEMS Microbiol Ecol 90:380-389 doi:10.1111/15746941.12395

Tourna MF, T. E.; Nicol, G. W.; Prosser, J. I. (2008) Growth, activity and temperature responses of ammonia-oxidizing archaea and bacteria in soil microcosms Environ Microbiol 10:1357-1364 doi:10.1111/j.1462-2920.2007.01563.x

Vinhal-Freitas IC, Ferreira AS, Corrêa GF, Wendling B (2012) Land Use Impact on Microbial and Biochemical Indicators in Agroecosystems of the Brazilian Cerrado Vadose Zone J 12:1-8

Weber EB, Lehtovirta-Morley LE, Prosser JI, Gubry-Rangin C (2015) Ammonia oxidation is not required for growth of Group 1.1c soil Thaumarchaeota FEMS Microbiol Ecol 91 doi:10.1093/femsec/fivoo1

Wertz S, Leigh AKK, Grayston SJ (2012) Effects of long-term fertilization of forest soils on potential nitrification and on the abundance and community structure of ammonia oxidizers and nitrite oxidizers FEMS Microbiol Ecol 79:142-154 doi:10.1111/j.1574$6941.2011 .01204 \cdot x$

Yu Z, Zhang Y, Luo W, Wang Y (2014) Root colonization and effect of biocontrol fungus Paecilomyces lilacinus on composition of ammonia-oxidizing bacteria, ammonia oxidizing archaea and fungal populations of tomato rhizosphere Biol Fert Soils 51:343351 doi:doi:10.1007/s00374-014-0983-y

Zhang LM, W. HH, P. SJ, Z. HJ (2012) Ammonia-oxidizing archaea have more important role than ammonia-oxidizing bacteria in ammonia oxidation of strongly acidic soils ISME J 6:10321045 doi:doi:10.1038/ismej.2011.168 
Figure Legends

Figure 1. Principal component analysis (PCA) of soil physicochemical properties based on a correlation matrix performed in PAST v.3.01 (Hammer et al. 2001). (A) Analysis of soybean site samples; (B) all samples including soil from the undisturbed Campo sujo site. Each vector points in the direction in which the respective value increases.

Figure 2. One-way ANOVA tests on soil $\mathrm{N}$ values, with Tukey-Kramer post hoc tests to compare group means (R with the ggplot2 package). Concentrations of (A) $\mathrm{NH}_{4}{ }^{+}-\mathrm{N}$ and (B) $\mathrm{NO}_{3}{ }^{-} \mathrm{N}$ in soil samples under each condition. (C) Net mineralization and (D) nitrification (D) determined by inorganic nitrogen- $\underline{\mathrm{N}}$ and $\mathrm{NO}_{3}{ }^{-}-\mathrm{N}$ content, respectively, measured after soil incubation in the laboratory for 1 week; (D) $\mathrm{NH}_{4}{ }^{+}-\mathrm{N}$ : $\mathrm{NO}_{3}{ }^{-}-\mathrm{N}$ ratio and (F) integrated values of soil $\delta^{15} \mathrm{~N}(\%)$. Letters represent significant differences in inorganic $\mathrm{N}$ content between soil samples after post hoc tests: upper case letters represent difference between undisturbed Campo sujo and fallow soil from the soybean site; lower case letters present differences among soybean site samples. Soil samples obtained during the blossom stage of soybean development are represented by Blossom-B for bulk soil and Blossom-R for rhizosphere soil.

Figure 3. Changes in (A) AOA amoA gene abundance, (B) AOB amoA gene abundance, (C) AOA:AOB amoA gene abundance ratio, and (D) archaeal 16S rRNA: amoA gene abundance ratio. Oneway ANOVA tests were performed, followed by Tukey-Kramer post hoc tests to compare group means (R package with the ggplot2 library). Different letters represent significant differences in gene abundance after post hoc tests: upper case letters represent difference between undisturbed Campo sujo and fallow soil from the soybean site; lower case letters present differences among soybean site samples. Soil samples obtained during the blossom stage of soybean development are represented by Blossom-B for bulk soil and Blossom-R for rhizosphere soil.

Figure S1. Gravimetric soil water content. Boxplot created by R version 3.0.2 with the ggplot 2 library. Letters and corresponding colors correspond to significant differences among groups after the TukeyKramer post hoc test.

Figure S2. Satellite view and photographs of the sample site on the Tabapuã dos Pireneus Farm. (A) Schematic representation of the sampling design on a Google Earth picture from the sample site. 1-3 represent composite samples for molecular analysis. (B)-(F) Photos of the soil collection sites. (B) 
Undisturbed Campo sujo site, (C)-(F) Soybean site at four different time points: (C) after 9 months of natural fallow, (D) 1 month after fertilization, (E) during the blossom stage of soybean development, (F) soybean plants with beans.

Figure S3. Relationship between soil $\delta^{13} \mathrm{C}$ and $\delta^{15} \mathrm{~N}$ in \%o. Each point represents samples from each soil condition, marked with different symbols. 


\author{
Ecology and molecular techniques reflect the short-term impacts of soybean management on \\ ammonia oxidizers in a Brazilian savanna under restoration \\ Molecular techniques and classical and isotopic analyses reflect the short-term impacts of \\ soybean management on ammonia oxidizers in a Brazilian savanna under restoration \\ Catão, E.C.P. ${ }^{1}$, Lopes, F.A.C. ${ }^{1}$; Rubini, M. R. ${ }^{1}$; Nardoto, G. B. ${ }^{2}$; Prosser, J.I. ${ }^{3}$; Krüger, R.H. ${ }^{1}$ \\ ${ }^{1}$ Departamento de Biologia Celular, Instituto de Biologia, Universidade de Brasília -Campus \\ Darcy Ribeiro, Brasília, Brazil, 700910-900 \\ ${ }^{2}$ Departamento de Ecologia, Instituto de Biologia, Universidade de Brasília -Campus Darcy \\ Ribeiro, 70910-900, Brasília, Brazil, 700910-900 \\ ${ }^{3}$ Institute of Biological and Environmental Sciences, University of Aberdeen, Cruickshank \\ Building, St. Machar Drive, Aberdeen AB24 3UU, UK \\ Corresponding author:

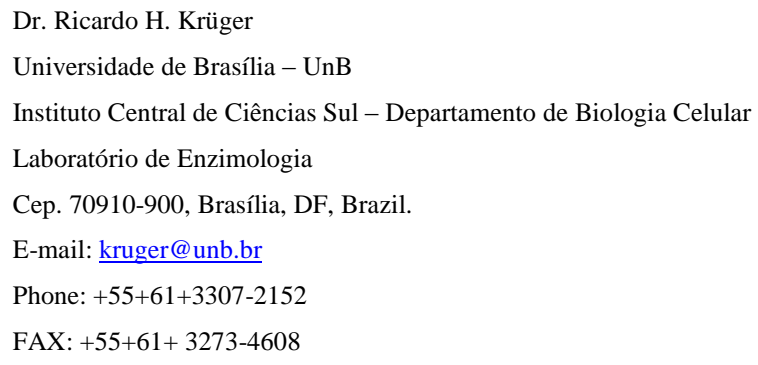

Running title: Short-term impact on ammonia oxidizers in Cerrado

Keywords: Ammonia oxidizers, amoA, nitrate, Central Brazilian Savanna, Cerrado, soybean

Acknowledgements: The authors are very grateful to Mr. Fabiano Bielefeld Nardotto, owner of the Tabapuã dos Pireneus farm, for allowing our free movement around the farm and collection of soil samples, as well as providing information about soybean cultivation. The authors also thank Dr. Plínio de Camargo, who performed the isotopic analysis in the CENA laboratory at the University of São Paulo (USP). This work was supported by grants from the National Council of Technological and Scientific Development (CNPq), Brazilian Federal Agency for Support and Evaluation of Graduate Education (CAPES), and Foundation for Research Support of Distrito Federal (FAP-DF) 
1

2

3

4

5

$8 \mid 40$

10

11

12

13

14

15

16

17

18

19

20

21

22

23

24

25

26

27

28

29

30

31

32

33

34

35

36

37

38

39

40

41

42

43

44

45

46

47

48

49

50

51

52

53

54

55

56

57

58

59

60

61

62

63

64

65 
41

\begin{abstract}
Interactions between soil characteristics and soil microbiota influence soil ecosystem processes such as nitrification; however, their complexity makes interpretation difficult. Furthermore, the impact of soil management systems on abundance and activity of soil microbial community and activity is poorly understood, especially in the Neotropics. To investigate these interactions, the effects of tillage, inorganic fertilization, and plant cover on the abundance of ammonia-oxidizing archaea (AOA) and ammonia-oxidizing bacteria (AOB) were assessed by quantification of the marker gene $(a m o A)$ during different stages of soybean cultivation in a site under restoration from gravel extraction in the Central Brazilian Savanna (Cerrado). Results of molecular analysis and classic and isotope techniques showed that levels of organic $\mathrm{C}$ and $\mathrm{NH}_{4}{ }^{+}-\mathrm{N}$ were higher in the soybean field during fallow than in an adjacent undisturbed field (Campo sujo). Ammonia oxidizer abundance and nitrification rates were also higher in the agricultural soil than in the undisturbed site, with the lowest ammonium:nitrate ratio in tilled soil. Soil $\delta^{15} \mathrm{~N}$ was lower in the undisturbed soil than the agricultural soil. Both $\mathrm{AOA}$ and $\mathrm{AOB}$ were more abundant during soybean crop transitional stages, and this increase positively correlated with soil $\mathrm{pH}$, particularly for АOB abundance, in tilled soil and within the soybean rhizosphere. The results suggest that AOB have more copiotrophic characteristics than AOA and are better able to change available ammonium in the soil. The combination of standard soil ecologicaly methods and modern molecular analysis show the short-term modification of ammonia oxidizer abundance and soil $\mathrm{N}$ dynamics in a managed system within the Cerrado biome.
\end{abstract}




\section{Introduction}

The impact of land use on the functioning of soil microbiota has consequences for the processes governed by these organisms and consequently for the terrestrial ecological services that they provide (e.g. decomposition and nutrient cycling). Agriculture and managed pasture for cattle breeding have converted approximately $53 \%\left(117,870 \mathrm{~km}^{2}\right)$ of the Cerrado biome landscape in the last two decades (Beuchle et al. 2015), with increasing alterations in floristic composition and edaphic characteristics due to fertilization, liming, and crop monoculture itself. Changes in soil use and management likely modify the $\mathrm{C}$ and $\mathrm{N}$ dynamics in these areas, leading to changes in soil $\mathrm{C}$ and $\mathrm{N}$ stocks and increases in greenhouse gas emissions to the atmosphere (Carvalho 2009).

Soil management and monoculture crops are associated with a decrease in total and microbial nitrogent $\underline{N}$, particularly in conventional tillage systems (Hernández-Hernández and López-Hernández 2002). In contrast, no-till management is associated with better soil quality and higher levels of enzyme activity (Peixoto et al. 2010) and microbial earbon $\underline{C}$ biomass (VinhalFreitas et al. 2012). In addition, no-till farming appears to have fewer effects on the composition of microbial communities (Rachid 2013). Previous research has shown that the soybean plant influences the composition of the soil microbial community, with lower microbial diversity observed during plant development in soils under soybean cultivation (Bresolin et al. 2010).

In the Amazonian forest, land use change alters functional gene diversity and the composition and abundance of soil microbial communities, with differences in soil $\mathrm{pH}$ and organic matter content linked to differences in the composition of genes, including those associated with 드 and $\underline{N}$ cycles (Paula et al. 2014). For example, $15 \%$ to $30 \%$ of genes related to the $\underline{N}$ cycle are modified by bioenergy crops (Zea mays and Miscanthus giganteus) (Mao et al. 2011), indicating that agriculture has an impact not only on microbial taxonomic composition but also on its potential ecological functions.

In view of the economic and ecological costs of fertilization and nitrogen $\underline{N}$ losses, it is important to investigate nitrifiers in Cerrado soils to develop better soil management practices. Undisturbed Cerrado soils under native vegetation have low $\mathrm{pH}$ and a high $\mathrm{NH}_{4}{ }^{+}{ }_{-} \mathrm{N}^{-} \mathrm{NO}_{3}{ }_{3}^{-}$ratio but very low nitrification rates (Nardoto and Bustamante 2003) and insignificant $\mathrm{N}_{2} \mathrm{O}$ emissions (Cruvinel et al. 2011; Pinto et al. 2006; 2002). These characteristics are often associated with a greater abundance of ammonia-oxidizing archaea (AOA) (Gubry-Rangin et al. 2011; GubryRangin et al. 2010; Nicol et al. 2008), which appear to prefer ammonia generated from the mineralization of organic $\mathrm{N}$ and are the predominant ammonia oxidizers in acid soils (LevičnikHöfferle et al. 2012; Prosser and Nicol 2012; Zhang et al. 2012). In contrast, ammonia-oxidizing bacteria $(\mathrm{AOB})$ are more commonly associated with nitrification in soils with higher ammonia input (Jia and Conrad 2009); therefore, the addition of inorganic or organic nitrogen $\underline{N}$ fertilizers may influence the relative abundance of AOA and AOB. The abundance of ammonia oxidizers, which perform the rate-limiting step of nitrification, can be estimated by amplification of the amo $A$ gene, which encodes subunit $\mathrm{A}$ of ammonia monooxygenase.

\section{Field Code Changed}

Field Code Changed

Field Code Changed

Field Code Changed

Field Code Changed

Field Code Changed

Field Code Changed

Field Code Changed

Field Code Changed

Field Code Changed

Field Code Changed

Field Code Changed

Field Code Changed

Field Code Changed

Field Code Changed

Field Code Changed

Field Code Changed 
Investigation of nitrification in the Cerrado biome is of particular interest because this ecosystem is nitrogenN-limited (Bustamante et al. 2012), with low nitrate content (Bustamante et al. 2006; Nardoto and Bustamante 2003) and low rates of nitrification (Nardoto and Bustamante 2003). These characteristics are usually associated with a high litter level and soil C:N ratio, leading to low availability of nitrogen $\underline{\mathrm{N}}$ and a higher rate of $\mathrm{N}$ immobilization than mineralization and Bustamante 2003).

Long-term land use is believed to modify the composition of soil microbial communities (Jangid et al. 2011; Paula et al. 2014), but few studies have described the short-term impacts (Lazcano et al. 2013). This study investigated the short-term effects of land use change, over 134 days, on ammonia oxidizers and tested the following hypotheses: 1) AOA are more abundant than AOB in undisturbed Campo sujo soil and in soybean site during the fallow period because of lower $\mathrm{pH}$ and provision of ammonium mainly by net $\mathrm{N}$ mineralization; 2) the relative abundance of $\mathrm{AOB}$ is greater in agricultural fertilized soil; and 3) the relative abundance of AOB increases during crop establishment due to the increase in $\mathrm{pH}$ and addition of inorganic fertilizers, which are associated with an increase in nitrate content and nitrification. To test these hypotheses, changes in archaeal and bacterial amoA gene abundance were determined by qPCR analysis in a soybean field and in soil from an adjacent undisturbed site (Campo sujo). This work describes short-term changes in the abundance of ammonia oxidizers in soil being restored after decades of gravel extraction in the Cerrado biome by evaluating the impact of soil management on microbial communities.
Field Code Changed

Field Code Changed 


\section{Materials and methods}

Study sites and soil characteristics

The field sites are located in the Cerrado biome within a commercial farm, Fazenda Tabapuã dos Pireneus, in the municipality of Cocalzinho de Goiás (Federal State of Goiás, Brazil). Average precipitation and temperature during sampling (134 days between the first and last days of sampling, October 13, 2012 and March 24, 2013, respectively), measured at the nearest meteorological center (approximately $30 \mathrm{~km}$ from the farm; Pirenopolis, GO, Station 83376, $15^{\circ} 50^{\prime} 60^{\prime \prime} \mathrm{S} 48^{\circ} 57^{\prime} 36^{\prime \prime} \mathrm{W}$ ), were $270 \mathrm{~mm}$ per month (Figure S1) and $24.8^{\circ} \mathrm{C}$ (range $19^{\circ} \mathrm{C}-32.5^{\circ} \mathrm{C}$ ) (Table S1). The climate in the Cerrado biome is tropical (Köppen Aw), and all soil samples were collected during the wet season (October to April), when $90 \%$ of the annual precipitation occurs.

This study focused on two sites: an undisturbed site dominated by grass and dispersed

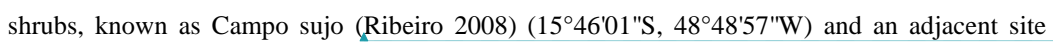
(approximately $200 \mathrm{~m}$ away) converted to soybean crop $\left(15^{\circ} 46^{\prime} 06^{\prime \prime} \mathrm{S}, 48^{\circ} 48^{\prime} 55^{\prime \prime} \mathrm{W}\right)$ (hereafter called the "soybean site"). Both sites have the same average altitude $(1118 \mathrm{~m})$, rainfall, and air temperature. The soybean site, which was degraded because of gravel removal activity that occurred over decades, is in the process of restoration to become an integrated livestock-forest system. It was first cultivated in 2012, with the establishment of maize followed by natural fallow. For maize cultivation a solution of $100 \mathrm{~kg} \mathrm{ha}^{-1}$ of NPK (8:30:16) and $200 \mathrm{~kg} \mathrm{ha}^{-1}$ urea were applied to the soil after plowing. Soybean seeds were then sowed after a 1-year fallow period. For soybean cultivation, an NPK mixture (8:30:16) and 8\% micronutrient mixture (FPE BR12) were added to the soil at $5 \mathrm{~cm}$ depth. The transgenic soybean Glycine $\max$ Bayer variety 810 was sowed (after inoculation with rhizobia) every $10 \mathrm{~cm}$ in rows separated by $50 \mathrm{~cm}$. Soil from the soybean site was sampled four times: after 9 months of natural fallow since the last maize cultivation (F; midOctober 2013); the day after the soil was tilled to a depth of $20 \mathrm{~cm}$ (T; first week of December 2012); 1 month after fertilization (FE, first week of January 2013); and at the blossom soybean stage of development (end of February 2013), at which time bulk soil (B) and rhizosphere soil (soil in direct contact with the root) (Rz) were sampled. To obtain soil from the rhizosphere, plants near the bulk soil sampling location were removed, the soil loosely surrounding the plant was released, and adherent soil at the rhizosphere was collected mechanically in a plastic bag. Figure S2 illustrates the treatments and the two study sites. Although crops in this farm are usually cultivated using no-till management, the history of gravel extraction in the soybean site necessitated use of a plow in deeper soil $(20 \mathrm{~cm})$. The farmer did not initially consider plowing, and only the top $10 \mathrm{~cm}$ (more active layer) was sampled.

Soil was obtained at nine locations at the two adjacent sites. The nine replicates were used for $\mathrm{N}$ concentration, $\mathrm{pH}$, and soil water content measurements. However, for the remaining physicochemical data, molecular, and $\delta^{15} \mathrm{~N}$ analysis, the samples were combined into triplicate samples, according to the column numbers presented in Figure S2. In the soybean site, samples were taken from the rows. At each location, 10 soil core samples (10 cm deep, $5 \mathrm{~cm}$ diameter) (Figure S2) were obtained, passed through a 2-mm mesh sieve, combined, and then stored at - 
$20^{\circ} \mathrm{C}$ for subsequent physicochemical and molecular analyses. Inorganic nitrogen $\underline{N}$ was extracted by agitating the soil sample for 1 hour in $1 \mathrm{M} \mathrm{KCl}$ (1:5 soil:solution ratio). $\mathrm{NH}_{4}{ }^{+}-\mathrm{N}$ was determined using the Nessler colorimetric method (Embrapa 1999) with a spectrophotometer set at $425 \mathrm{~nm}$. $\mathrm{NO}_{3}-\mathrm{N}$ was determined by spectrophotometry (Mulvaney 1996) at $218 \mathrm{~nm}$, subtracting interference caused by organic matter at 254 and $280 \mathrm{~nm}$ (Meier 1991). These measurements were considered time zero and compared with $\mathrm{NH}_{4}{ }^{+}-\mathrm{N}$ and $\mathrm{NO}_{3}{ }^{-} \mathrm{-N}$ measurements after samples were incubated in the laboratory in separate closed plastic bags for 7 days at room temperature in the dark (Piccolo et al. 1994). Net changes in $\mathrm{NH}_{4}{ }^{+}-\mathrm{N}+\mathrm{NO}_{3}^{-}-\mathrm{N}$ or $\mathrm{NO}_{3}{ }^{-}-\mathrm{N}$, respectively, during the 7 days of incubation. All results are expressed $\mathrm{g}^{-1}$ oven-dried $\left(105^{\circ} \mathrm{C}\right)$ soil.

Physicochemical and molecular analyses were performed in biological triplicates. Soil texture and concentrations of macro- and micronutrients were determined by using standard methods (Soils Embrapa-SNLCS) at SoloQuímica, Inc, Brasília, Brazil. Both soils are wellaerated and well-drained. The undisturbed Campo sujo soil is classified as sandy loam with $20.8 \%$ clay, and the soybean site is in a sandy clay soil with $31.7 \%$ clay. Both soils are considered to have a medium clay texture (Embrapa 2006) (Table 1). This work is not meant to compare the sites but to describe the rapid change in ammonia oxidizer abundance during the establishment of a soybean crop. The undisturbed site was used as a control to represent nitrification in a pristine Cerrado area.

\section{Isotope analysis}

All soil samples were air-dried and ground to a fine powder. A sub-sample of 15 to $20 \mathrm{mg}$ was sealed in a tin capsule and loaded into a ThermoQuest-Finnigan Delta Plus isotope ratio mass spectrometer (Finnigan-MAT; CA, USA) coupled with an elemental analyzer (Carlo Erba model 1110; Milan, Italy). These analyses were performed at Centro de Energia Nuclear na Agricultura (CENA - USP) in Piracicaba, Brazil. The natural abundance of stable isotopes of $\mathrm{C}$ and $\mathrm{N}$ were measured in relation to recognized international standards. As standard laboratory procedure, internal working standards (Atropine and soil standard no. 502-308 from LECO Corporation) were included in every run. Relative stable isotope values are reported in "delta" notation, as $\delta$ values in parts per thousand (\%) according to the molar ratio (R) of the rare to abundant isotope $\left({ }^{15} \mathrm{~N} /{ }^{14} \mathrm{~N}\right.$; $\left.{ }^{13} \mathrm{C} /{ }^{12} \mathrm{C}\right)$, i.e. $\delta \%=\left(\mathrm{R}_{\text {sample }} / \mathrm{R}_{\text {standard }}-1\right) \times 1000$. The precision of measurements was \pm 0.3 and $0.5 \%$ for $\delta^{13} \mathrm{C}$ and $\delta^{15} \mathrm{~N}$, respectively.

\section{DNA extraction}

DNA was extracted from $0.5 \mathrm{~g}$ soil using the FastDNA Spin Kit (MP Biomedicals) with additional treatment using solutions 2 and 3 from the PowerSoil DNA Isolation Kit (MO Bio Laboratories Inc.) to achieve maximum DNA yields with the least organic contamination. The DNA was analyzed by $1 \%(\mathrm{w} / \mathrm{v})$ agarose gel electrophoresis. The average concentration of each 24 DNA sample (24 in total) was $100 \mathrm{ng} \mu \mathrm{L}^{-1}$ (Invitrogen Qubit fluorometer dsDNA BR Kit).

\begin{tabular}{|l|}
\hline Field Code Changed \\
\hline Field Code Changed \\
\hline Field Code Changed \\
\hline
\end{tabular}

Field Code Changed 


\section{Real-time PCR}

Thaumarchaeota 16S rRNA and archaeal and bacterial amoA genes were amplified in an Eppendorf Mastercycler and quantified using standard curves. Each $20-\mu 1$ reaction contained $1 \mathrm{X}$ QuantiFast master mix (for AOA) or QuantiTect master mix (for AOB) (Qiagen), $0.4 \mu \mathrm{M}$ primers (archaeal 16S rRNA, AOA amoA) or $0.6 \mu \mathrm{M}$ primers (AOB $a m o A$ ), $2 \mu \mathrm{g} \mu^{-1}$ bovine serum albumin (Promega), and 5 ng DNA. The thaumarchaeal 16S rRNA gene was amplified with the $771 \mathrm{f}$ and 958r primers (Ochsenreiter et al. 2003), the AOA amoA gene with the crenamo23f and crenamo616r primers (Tourna 2008), and the AOB amoA gene with the amoA1F and amoA2R primers (Rotthauwe et al. 1997). Cycling conditions were as follows: $15 \mathrm{~min}$ at $95^{\circ} \mathrm{C}$ followed by 40 cycles of $15 \mathrm{~s}$ at $94^{\circ} \mathrm{C}$ and $1 \mathrm{~min} 30 \mathrm{~s}$ at $60^{\circ} \mathrm{C}$ for the $\mathrm{AOA}$ amoA gene; and $15 \mathrm{~min}$ at $95^{\circ} \mathrm{C}$ followed by 45 cycles of $1 \mathrm{~min}$ at $94^{\circ} \mathrm{C}, 1 \mathrm{~min}$ at $55^{\circ} \mathrm{C}$, and $1 \mathrm{~min}$ at $72^{\circ} \mathrm{C}$ for the $\mathrm{AOB} a m o A$ gene. Fluorescence was measured after $5 \mathrm{~s}$ at $80^{\circ} \mathrm{C}(\mathrm{AOA} a m o A)$ or $8 \mathrm{~s}$ at $83^{\circ} \mathrm{C}(\mathrm{AOB} a m o A)$ to exclude fluorescence contamination of potential primer-dimers. Melting curves between $65^{\circ} \mathrm{C}$ and $95^{\circ} \mathrm{C}$ were analyzed for each run.

Standards were made from 10-fold dilutions of the fragment of the gene of interest. This fragment was obtained by amplification of the genes with the respective primers from a composite of the soil samples used in this work. The fragment was cloned into a pGEM®-T Easy Vector (Promega) and re-amplified using M13 primers that recognize sites flanking the cloned fragment. Three clones of each gene were selected and verified by Sanger sequencing. The longer and more accurate sequence was chosen as the standard. Plasmid DNA concentrations were verified using a Qubit 2.0 fluorometer (Life Technologies) and NanoDrop 1000 spectrophotometer (Thermo Scientific). To verify the correct size of individual PCR products, melting curve and agarose gel electrophoresis analyses were performed. To exclude the fluorescence from potential primerdimers, fluorescence was captured after each amplification cycle above $80^{\circ} \mathrm{C}$. Efficiency of amplification and $r^{2}$ values were 0.86 and 0.990 for archaeal 16S rRNA, 0.92 and 0.995 for archaeal $a m o A$, and 0.86 and 0.994 for bacterial amoA, respectively. No inhibition was detected in assays consisting of soil DNA diluted in water or with a known amount of standard DNA.

\section{Statistical Analysis}

Statistical analyses were performed in R (v 3.0.2), and all qPCR and physicochemical data were analyzed for normality and homoscedasticity with both Kolmogorov-Smirnov and Levene's test statistics. Data that did not follow a normal distribution were log-transformed. One-way ANOVA tests were used to make multiple comparisons, with Tukey-Kramer post hoc tests to compare the group means shown in the graphs with different letters and corresponding colors. All graphs in the boxplot format were prepared in $\mathrm{R}$ with the ggplot2 library, in which the default is to present the upper and lower sides of the box as the first and third quartile, whiskers corresponding to the highest and lowest values within 1.5 interquartile range (IQR), and dots representing outliers outside the IQR. The Pearson correlation was used to evaluate relationships between qPCR data and physiochemical variables with relevant biological implications (i.e., $\mathrm{pH}$, net nitrification rate,

\begin{tabular}{|l|}
\hline Field Code Changed \\
\hline Field Code Changed \\
\hline Field Code Changed \\
\hline
\end{tabular}


1

2

3

4

7 $\left.\delta^{15} \mathrm{~N}\right)$. The Bonferroni (Rice 1989) or Benjamini-Hochberg (BH) (Benjamini and Hochberg 1995) methods were used to correct $p$-values for multiple comparisons; the Bonferroni correction is more conservative.
9
Field Code Changed

Field Code Changed 


\section{Results}

Description of study sites and soil physicochemical characteristics

Water content of the undisturbed soil was lower than that of the soybean site at all time points, including soil collected on the same day in the soybean site during fallow. This finding may reflect differences in soil texture (Figure S1). Fallow soil from the soybean site contained residual material from the previous maize cultivation. Before sowing, 2 ton ha ${ }^{-1}$ limestone was applied to the soil, which increased soil $\mathrm{pH}$ in $\mathrm{H}_{2} \mathrm{O}$ from 5.5 (4.3 in $\mathrm{KCl}$ ) to 6 (5.2 in $\mathrm{KCl}$ ). The undisturbed Campo sujo soil had lower $\mathrm{pH}$ values (5.4 in $\mathrm{H}_{2} \mathrm{O}$ and 3.6 in $\mathrm{KCl}$ ) (Table $\mathrm{S} 1$ ).

Principal component analysis of soil physicochemical data (Figure 1) indicated that the physicochemical characteristics in the fallow soil differed significantly from soil collected in the soybean site at the other time points (Figure 1A). The undisturbed soil also differed from the fallow soil from the soybean site, which had higher organic $\mathrm{C}$ and $\mathrm{NH}_{4}{ }^{+}-\mathrm{N}$ concentrations (Figure 1B). However, other soils obtained from the soybean site clustered together, indicating similar physicochemical characteristics. In particular, these soils had higher $\mathrm{pH}$ and levels of nitrate, water, and micronutrients compared to the undisturbed Campo sujo soil and fallow soil (Figure 1B).

Ammonium and nitrate concentrations and soil $\delta^{15} \mathrm{~N}$

$\mathrm{NH}_{4}{ }^{+}-\mathrm{N}$ concentration in the undisturbed Campo sujo soil generally ranged from 5 to $8.3 \mu \mathrm{g} \mathrm{g}^{-1}$ dry soil, with two outliers of 11.8 and $48.7 \mu \mathrm{g} \mathrm{g}^{-1} \mathrm{dry}$ soil (Figure $2 \mathrm{~A}$ ). The potential net $\mathrm{N}$ mineralization rate, determined by incubation of soil in the laboratory at room temperature, indicated that $\mathrm{NH}_{4}{ }^{+}-\mathrm{N}$ was becoming available in these soils at a rate of 0.8 to $3.29 \mathrm{NH}_{4}{ }^{+}-\mathrm{N} \mu \mathrm{g} \mathrm{g}$ ${ }^{1} \mathrm{dry}$ soil day ${ }^{-1}$ (Figure 2C). The

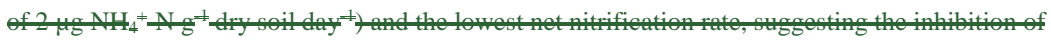

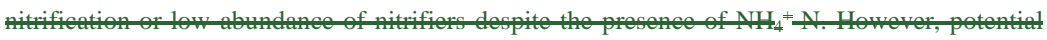

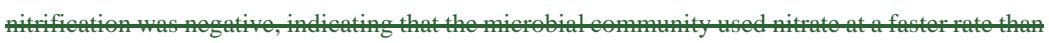

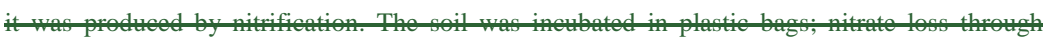
leaching is negligible. Denitrification is unlikely at the moisture content of the soil used, and previous studies report that the loss of $\mathrm{N}$ gases is undetectable in undisturbed Cerrado soils $\mathrm{NH}_{4}{ }^{+}-\mathrm{N}$ concentration was higher than $\mathrm{NO}_{3}{ }^{-}-\mathrm{N}$ concentration in every soil sample but was particularly high in the undisturbed Campo sujo soil (Figure 2E). Fallow, tilled, and fertilized soils of the soybean site had similar average $\mathrm{NO}_{3}{ }^{-}-\mathrm{N}$ concentrations, which were higher than that of the bulk soil and rhizosphere soil collected during the blossom stage (Figure 2B). Nitrification was greater in fallow soil from the soybean site than in undisturbed Campo sujo soil (Figure 2D). Analysis of the soybean site samples showed a decrease in $\mathrm{NH}_{4}{ }^{+}-\mathrm{N}$ concentration as the crop developed, with significantly lower concentration in tilled soil and soil collected during the blossom stage of soybean development (both bulk and rhizosphere soils) than in fallow soil (Figure 2A). Nitrogen immobilization was greater than mineralization in fallow soil, recently tilled soil, bulk soil during the blossom stage, and especially in soil collected 1 month after fertilization. 
Nonetheless, the average net $\mathrm{N}$ mineralization differed significantly only between fertilized soil and soil collected during the blossom stage (both bulk and rhizosphere soils) (Figure 2C). Because fertilization was carried out at the same time as sowing, plant growth may have influenced the results obtained from soil collected 1 month after fertilization through $\mathrm{NH}_{4}{ }^{+}-\mathrm{N}$ uptake and the low inorganic $\mathrm{N}$ content in soil collected during the blossom stage. However, net $\mathrm{N}$ mineralization and nitrification occurred in a plant-free soil bag under laboratory conditions; therefore, $\mathrm{NH}_{4}{ }^{+}$would have been assimilated by microorganisms or oxidized to $\mathrm{NO}_{3}{ }^{-}$by nitrifiers.

Another informative parameter was the $\mathrm{NH}_{4}{ }^{+}-\mathrm{N}^{-} \mathrm{NO}_{3}{ }^{-} \mathrm{N}$ ratio, with the lowest ratio observed in tilled soil, emphasizing the need for mineral $\mathrm{N}$ by the plants and soil microbial community during the blossom stage (Figure 2E). Figure 2E also shows the high ammonium:nitrate ratio in the undisturbed Campo sujo soil.

These results were supported by the integrated stable isotope ratios of $\mathrm{C}$ and $\mathrm{N}$ in these soils. The first soybean (C3 plant) cultivation did not change the $\delta^{13} \mathrm{C}$ signal that remained from maize (C4 plant) cultivation or from the grassland before agriculture installation (Figure S3); however, the integrated soil $\delta^{15} \mathrm{~N}$ values were more labile. Soil $\delta^{15} \mathrm{~N}$ was significantly lower in the undisturbed Campo sujo soil than in fallow soil from the soybean site (Figure 2F). Although soil $\delta^{15} \mathrm{~N}$ did not significantly change during the soybean cultivation period, an increase was observed during the blossom stage ( $p$-value 0.0795 , results of ANOVA between samples from the soybean site) (Figure 2F). These integrated isotope values are congruent with instantaneous values for mineralization and nitrification obtained from each sample in which significant changes in $\mathrm{N}$ cycle dynamics were observed, compared to the adjacent undisturbed site.

Abundance of archaeal and bacterial amoA genes

Archaeal 16S rRNA and archaeal and bacterial amoA genes were amplified with specific primers to quantify the abundance of these genes in the undisturbed site and in the soybean site.

The mean abundances of AOA and $\mathrm{AOB} a m o A$ genes in the undisturbed Campo sujo site were $3.4 \times 10^{5}$ and $1.6 \times 10^{3} \mathrm{~g}^{-1}$ dry soil, respectively, representing an average AOA:AOB ratio of 212.9 (Figure 3C). In addition, AOA and AOB were, respectively, 26-fold and 49-fold less abundant in the Campo sujo site than the soybean site during the fallow period (Figure 3). The thaumarchaeal 16S rRNA:archaeal amoA gene ratio in the Campo sujo site varied from 785 to 1340 and was significantly higher than that of fallow soil from the soybean site. This result, which may be due to primer bias, indicates that not all archaea in the samples were ammonia oxidizers (Figure 3D).

The abundance of thaumarchaeal 16S rRNA and bacterial amoA increased during soybean development, but AOA amoA gene abundance decreased by $45 \%$ in the tilled soil compared to fallow soil. Tillage did not have the same effect on AOB, as demonstrated by the lack of significant change in $\mathrm{AOB}$ amoA gene abundance between fallow and tilled soil samples (Figure 3B). In fertilized soil AOA amoA gene abundance increased 2.6-fold and AOB amoA abundance increased 2-fold (Figure 3). However, AOB amoA gene abundance was more affected by soybean cultivation 
than AOA amoA gene abundance, as demonstrated by comparingson of rhizosphere soil with bulk soil during the blossom stage of soybean development. Furthermore, the increase in AOB abundance from fallow soil to rhizosphere soil was 2.9 greater than the increase in AOA abundance.

Soybean cultivation affected the abundance of both bacterial and archaeal ammonia oxidizers. This finding may be explained by the increase in soil $\mathrm{pH}$ compared to the Campo sujo soil, which was one of the largest changes observed in the soil during soybean cultivation. The correlation between $\mathrm{pH}$ measured in $\mathrm{H}_{2} \mathrm{O}$ and $\log _{10}[\mathrm{AOB}]\left(\mathrm{R}^{2} 0.75\right.$, $p$-value $<0.05$ with the Bonferroni correction) was higher than the correlation between $\mathrm{pH}$ and $\log _{10}[\mathrm{AOA}]\left(\mathrm{R}^{2} 0.63, p\right.$ value $<0.05$ with the $\mathrm{BH}$ correction). Similarly, the pattern of $\delta^{15} \mathrm{~N}$ was more strongly associated with $\log _{10}[\mathrm{AOB}]\left(\mathrm{R}^{2} 0.96, p\right.$-value $<0.05$ corrected by Bonferroni method) than with $\log _{10}[\mathrm{AOA}]$ $\left(\mathrm{R}^{2} 0.88, p\right.$-value $<0.05$ with the Bonferroni correction). Nevertheless, when analyzing only soils from the soybean site, $\mathrm{AOA}$ abundance did not correlate with $\mathrm{pH}$, and the correlation between $\mathrm{pH}$ and $\mathrm{AOB}$ abundance was lower $\left(\mathrm{R}^{2} 0.55, p\right.$-value $=0.72$ with the Bonferroni correction). Similarly, the correlation between $\delta^{15} \mathrm{~N}$ and $\log _{10}[\mathrm{AOA}]$ was not significant $\left(\mathrm{R}^{2} 0.24\right.$, $p$-value $=0.64$ corrected by BH method) when analyzing only soils from the soybean site, but the correlation was still significant between $\delta^{15} \mathrm{~N}$ and $\log _{10}[\mathrm{AOB}]\left(\mathrm{R}^{2} 0.68, p\right.$-value $<0.05$ with the $\mathrm{BH}$ correction).

\section{Discussion}

In assessing links between environmental characteristics, nitrification, and the abundance of ammonia-oxidizer communities in the soil, it is important to assess abundances of both AOA and AOB, given the predominance of AOA amoA genes in many soils (Isobe 2012; Leininger 2006; Prosser and Nicol 2012). To assess the impact of land use conversion to soybean cultivation, ammonia oxidizer abundance and nitrification were evaluated in a soybean site after fallow, tillage, and fertilization and during the blossom stage of soybean development. These measurements were compared with those of an adjacent undisturbed Campo sujo site with low nitrate concentration, which is typical of Cerrado soil. These measurements support our hypothesis that both fertilization and soybean cultivation decrease the AOA:AOB ratio in association with increases in $\mathrm{pH}$ (Nicol et al. 2008; Prosser and Nicol 2012) and inorganic $\mathrm{NH}_{4}{ }^{+}$(Levičnik-Höfferle et al. 2012), which is consistent with studies reporting that AOA are predominant in low-nutrient, low-pH environments (Erguder et al. 2009; Prosser and Nicol 2012). However, this study highlights the rapidity of changes in nitrifiers, $\mathrm{N}$ dynamics, and yields that occur in Cerrado soils after conversion to soybean cultivation.

The cultivation of soybeans in Brazil has been successfully implemented with inoculation of Bradyrhizobium strains to decrease or even completely eliminate the need for nitrogen $\underline{\underline{N}}$ fertilizers (Mendes et al. 2003). Nevertheless, the soybean site studied here required tillage and fertilization. Our results showed the effect of plant cover during the fallow period on soil recovery in the soybean site. Soil collected during the fallow period had soil characteristics similar to those of the undisturbed Campo sujo site, despite the different soil texture.

Field Code Changed

Field Code Changed

Field Code Changed 
The undisturbed soil had the highest net $\mathrm{N}$ mineralization rate (average of $2 \mu \mathrm{g} \mathrm{NH}{ }_{4}^{+}-\mathrm{N}$ $\mathrm{g}^{-1} \mathrm{dry}$ soil day $\mathrm{d}^{-1}$ ) and the lowest net nitrification rate, suggesting the inhibition of nitrification or low abundance of nitrifiers despite the presence of $\mathrm{NH}_{4}{ }^{+}-\mathrm{N}$. However, potential nitrification was negative, indicating that the microbial community used nitrate at a faster rate than it was produced by nitrification. The soil was incubated in plastic bags; nitrate loss through leaching is negligible. Denitrification is unlikely at the moisture content of the soil used, and previous studies report that the loss of $\mathrm{N}$ gases is undetectable in undisturbed Cerrado soils (Bustamante et al. 2006; Pinto et al. 2002)=

Both $\mathrm{NH}_{4}{ }^{+}-\mathrm{N}$ and $\mathrm{NO}_{3}{ }^{-}-\mathrm{N}$ concentrations were particularly low in the soybean site during the blossom stage of soybean development, possibly because of $\mathrm{N}$ uptake by the soybean plants. $\mathrm{N}$ mineralization exceeded immobilization in the rhizosphere soil but not in the bulk soil, which suggests greater nitrogen $\underline{\underline{N}}$ availability due to symbiotic nitrogen $\underline{\underline{N}}$ fixation. The soil C:N ratio > 20 (data not shown) in the bulk soil may partly explain the greater $\mathrm{N}$ immobilization, leading to depletion of $\mathrm{N}$ by both microbiota and plants.

The decrease in $\mathrm{NH}_{4}{ }^{+}-\mathrm{N}$ and $\mathrm{NO}_{3}{ }^{-} \mathrm{N}$ during soybean growth was expected and is associated with periods of intense plant growth (Cruvinel et al. 2011). Nevertheless, Cruvinel et al. (2011) reported higher concentrations of $\mathrm{NO}_{3}^{-}-\mathrm{N}\left(1-52 \mathrm{mg} \mathrm{kg}^{-1}\right.$, depending on the period) and $\mathrm{NH}_{4}{ }^{+}-\mathrm{N}\left(21.3-50.7 \mathrm{mg} \mathrm{NH}_{4}{ }^{+}-\mathrm{N} \mathrm{kg}^{-1}\right.$ soil) in soils during soybean cultivation higher than the levels of $\mathrm{NO}_{3}{ }^{-}-\mathrm{N}$ and $\mathrm{NH}_{4}{ }^{+}-\mathrm{N}$ concentration-deseribed here from a in the soybean site in recovery, supporting our finding that the soils sampled in our study were relatively depleted in mineral

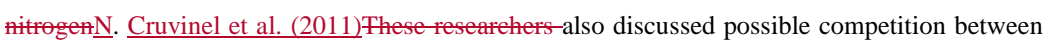
plant roots and microorganisms in the planted rows during cotton cultivation in the Cerrado because of the lower inorganic nitregen $\mathrm{N}$ availability and NO-N fluxes than that observed between rows (Cruvinel 2011). Low abundance of AOA and AOB in Cerrado soils may be due to competition with soil fungi for ammonium or inhibition by bioactive compounds synthesized by fungi (Yu et al. 2014). Nardoto and Bustamante (2003) showed that in both burned and unburned Cerrado areas, inorganic nitrogen $\underline{N}$ content decreases during the rainy season, despite the observed increase in net $\mathrm{N}$ mineralization and net nitrification after the first rainfall events of the dry season (Nardoto and Bustamante 2003). These studies are consistent with our findings, as soils have higher levels of ammonia than nitrate, and the ammonium:nitrate ratio was lowest in the tilled soil, likely due to nitrogen $\underline{\mathrm{N}}$ release from organic matter. Similarly, the ammonium:nitrate ratio is high in integrated agricultural systems in Cerrado but is lower in crop-livestock and croplivestock-forest systems compared to agroforestry and exotic pasture (Carvalho et al., personal communication). The same study also reports higher $\mathrm{N}_{2} \mathrm{O}$ emissions from all of these agricultural systems compared with native Cerrado soils, with crop-livestock having the highest levels (Carvalho et al., personal communication).

Despite lower soil nitrate concentrations than those reported by other studies, $\mathrm{N}$ losses from the soybean site compared with the undisturbed Campo sujo site are suggested by higher $\delta^{15} \mathrm{~N}$ values and greater nitrate accumulation in the managed system. The integrative soil $\delta^{15} \mathrm{~N}$

Field Code Changed

Field Code Changed

Field Code Changed 
signal, which provides historical information on soil nitrogen $\mathrm{N}$ dynamics, indicates that soybean cultivation affects soil $\mathrm{N}$ accumulation, as the expected values for symbiotic nitregen $\mathrm{N}$ fixation are-were lower, at 0-2\%o (Delwiche et al. 1979). Nonetheless, the results demonstrate the labile characteristics of nitrogen $\underline{\mathrm{N}}$ compared to earben $\underline{\mathrm{C}}$, as $\delta^{15} \mathrm{~N}$ tended to increase during soybean cultivation, changing the short-term $\mathrm{N}$ dynamics in the cultivated soil, whereas no significant changes in $\delta^{13} \mathrm{C}$ were observed. A recent study reported that the $\delta^{15} \mathrm{~N}$ signature reflects a strong pattern of change according to land use, mainly due to soil earben $\underline{C}$ dynamics and clay content JME 2015).

Many soil characteristics are associated with changes in soil nitrification, including $\mathrm{pH}$ (Gubry-Rangin et al. 2011; Nicol et al. 2008), $\mathrm{NH}_{3}$ and $\mathrm{NH}_{3}^{+}$concentration ammonia quality and quantity (Levičnik-Höfferle et al. 2012; Stopnisek 2010), $\mathrm{O}_{2}$ (Erguder et al. 2009), temperature (Tourna 2008), soil moisture (Placella and Firestone 2013; Thion and Prosser 2014), and organic earbon- $\underline{C}$ (Erguder et al. 2009); however, $\mathrm{pH}$ and ammonia concentration have received greatest attention as potential drivers of ammonia oxidizer communities (Prosser and Nicol 2012). Kinetic studies of ammonia oxidation by Nitrosopumilus maritimus suggest that AOA have a higher affinity for ammonia (Martens-Habbena et al. 2009), but AOA may also be more sensitive than AOB to inhibition by high ammonia concentration (Prosser and Nicol 2012). In terms of pH, there is strong evidence for the selection of AOA, rather than AOB, in acid soils (Gubry-Rangin et al. 2011; Nicol et al. 2008; Zhang et al. 2012). However, AOA also contribute to nitrification in soils with $\mathrm{pH}>5.5$ (Gubry-Rangin et al. 2011; Gubry-Rangin et al. 2010), and there is evidence for long-term pH selection of both AOB and AOA phylotypes in soil (Nicol et al. 2008; Stephen et al. 1998). The increased $\mathrm{pH}$ observed during soybean cultivation was associated with a lower AOA:AOB ratio in our study, but no significant effect on nitrification was detected, and the expected decrease in $\mathrm{pH}$ that frequently accompanies nitrification was not observed. This may be due to liming or the low rates of ammonia oxidation observed in these soils. Therefore, $\mathrm{pH}$ may limit ammonia oxidizer growth in these low-nitrate Cerrado soils.

In this study we observed that tillage, fertilization, liming, and soybean monoculture altered soil $\mathrm{pH}$, moisture, and inorganic $\mathrm{N}$ contents, all of which can influence the abundance and diversity of microbial communities and their functional potential, thereby influencing the production of nitrate, nitrite, $\mathrm{NO}$, and $\mathrm{N}_{2} \mathrm{O}$ (Mao et al. 2011). The change in land use had differential effects on the abundance of $\mathrm{AOA}$ and $\mathrm{AOB}$ communities, reinforcing the idea that these two microbial groups have distinct ecological niches associated with environmental variables. Specifically, samples from recently tilled soil and soil collected from the rhizosphere had smaller $\mathrm{AOA}$ : $\mathrm{AOB}$ ratios, and $\mathrm{AOB}$ showed a greater response to changes occurring during soybean cultivation. The lower abundance of AOA in undisturbed soil can be also related to the higher thaumarchaeal 16S rRNA:archaeal amoA ratio, which, in the absence of primer bias, indicates a great abundance of non-ammonia-oxidizing Thaumarchaeota (e.g., belonging to group 1.1c) (Weber et al. 2015).

Field Code Changed

Field Code Changed

\begin{tabular}{|l|}
\hline Field Code Changed \\
\hline Formatted: Subscript \\
\hline Field Code Changed \\
\hline Formatted: Not Superscript/ Subscript \\
\hline Formatted: Superscript \\
\hline Field Code Changed \\
\hline Field Code Changed \\
\hline Field Code Changed \\
\hline Field Code Changed \\
\hline Field Code Changed \\
\hline Field Code Changed \\
\hline Field Code Changed \\
\hline Field Code Changed \\
\hline Field Code Changed \\
\hline Field Code Changed \\
\hline Field Code Changed \\
\hline Field Code Changed \\
\hline Field Code Changed \\
\hline Field Code Changed \\
\hline Field Code Changed \\
\hline Field Code Changed \\
\hline Field Code Changed \\
\hline Field Code Changed \\
\hline
\end{tabular}


A recent metagenomic study reported that Thaumarchaeota representatives were more abundant in no-till soils than in soils under conventional tillage (Souza 2013), possibly because of greater organic matter content or sensitivity to tillage. Although the AOA amoA gene was more abundant in all of our soil samples, the increase in $\mathrm{AOB}$ amoA abundance in tilled soil was greater. This finding may reflect the disruption of soil structure and release of $\mathrm{C}$ and $\mathrm{N}$ substrates previously not available to the microbiota.

Our results provided evidence for our hypothesis that both $\mathrm{AOA}$ and $\mathrm{AOB}$ abundance increase during soybean cultivation, with $\mathrm{AOB}$ increasing more than $\mathrm{AOA}$, as predicted. Although AOA were more abundant, nitrification was better explained by the increase in $\mathrm{AOB}$ abundance, as predicted by the current view that $\mathrm{AOB}$ contribute more to ammonia oxidation than $\mathrm{AOA}$ in fertilized oxic soils at near-neutral pH. Wertz et al. (2012) reported an increase in AOB abundance with fertilizer application and nitrification in pine forests (Wertz et al. 2012), , but more recent work suggests more dynamic changes in $\mathrm{AOA}$ than $\mathrm{AOB}$. However, $\mathrm{AOB}$ abundance was more highly correlated with potential nitrification (Meyer et al. 2014), indicating that other factors can influence ammonia oxidizer communities. Moreover, although AOA abundance is potentially stable during the cultivation of bioenergy crops (Zea mays and Miscanthus giganteus), AOA diversity decreases, and $\mathrm{AOB}$ abundance increases, with this differential response to fertilization by AOA and AOB observed even 2 years after the fertilization (Mao et al. 2011).

A similar increase in the abundance of $\mathrm{AOB}$, rather than $\mathrm{AOA}$, was reported for a fertilized maize crop (Mao et al. 2011), and Mendes et al. (2014) recently showed that soybean plants select for the rhizosphere a specific subset of the soil bulk microbial community, which appears to be related to growth promotion and nutrition (Mao et al. 2011; Mendes 2014). Further studies are required to elucidate the differential effect of soybean cultivation on AOA and АOB abundance to determine whether these differences are direct effects of the soybean plant or due to fertilization promoting the growth of AOB.

\section{Conclusions}

Our study showed a rapid turnover (less than 1 year) of microbial communities and soil chemical properties due to anthropogenic impact in Cerrado soils. Land use changes promote differential short-term effects on nitrification rates and $\mathrm{AOA}$ and $\mathrm{AOB}$ abundance, suggesting that these groups have different physiological characteristics with respect to nutrient availability. Results of molecular data and soil ecological analyses are complementary and provide insights into the impact of soybean management on ammonia oxidizers in an area under restoration in the Cerrado biome. Our results confirm the dominance of AOA in soils collected at the field site in Cocalzinho de Goiás (GO). These results are consistent with the low $\mathrm{pH}$ and nitrification rates observed in Cerrado soils in general. We found that despite ammonium availability in the undisturbed Campo sujo soil, the abundance of ammonia oxidizers was low, as determined by amoA gene amplification. Nevertheless, soybean cultivation altered both AOA and AOB abundance, with the

\section{Field Code Changed}

Field Code Changed

Field Code Changed

Field Code Changed

Field Code Changed

Field Code Changed

Field Code Changed 
1

2

3

4 soybean plants, nitrification rate, and $\mathrm{pH}$ affecting $\mathrm{AOB}$ more than AOA. Although these changes were observed in a small area, they suggest processes that occur on a larger scale. 
1

2

3

4

848

$\begin{array}{ll}9 & 482\end{array}$

10483

12

13

14

15

16

17

18

19

20

21

22

23

24

25

26

27

28

29

30

31

32

33

34

35

36

37

38

39

40

41

42

43

44

45

46

47

48

49

50

51

52

53

54

55

56

57

58

59

60

61

62

63

64

65

Conflict of interest: The authors declare no conflict of interest. 


\section{References}

Benjamini Y, Hochberg Y (1995) Controlling the False Discovery Rate - a Practical and Powerful Approach to Multiple Testing J Roy Stat Soc B Met 57:289-300

Beuchle R, Grecchi RC, Shimabukuro YE, Seliger R (2015) Land cover changes in the Brazilian Cerrado and Caatinga biomes from 1990 to 2010 based on a systematic remote sensing sampling approach Appl Geogr 58:116-127

Bresolin JD, Bustamante MM, Kruger RH, Silva MR, Perez KS (2010) Structure and composition of bacterial and fungal community in soil under soybean monoculture in the Brazilian Cerrado Braz J Microbiol 41:391-403 doi:10.1590/S1517838220100002000021

Bustamante MM, Nardoto GB, Pinto AS, Resende JC, Takahashi FS, Vieira LC (2012) Potential impacts of climate change on biogeochemical functioning of Cerrado ecosystems Braz J Biol 72:655-671 doi:10.1590/S1519-69842012000400005

Bustamante MMC, Medina E, Asner GP, Nardoto GB, Garcia-Montiel DC (2006) Nitrogen cycling in tropical and temperate savannas Biogeochemistry 79:209-237

Carvalho JLNC, J. L. N., Cerri, C. E. P., Feigl, B. J., Piccolo, M. C., Godinho, V. P., \& Cerri, C. C. (2009) Carbon sequestration in agricultural soils in the Cerrado region of the Brazilian Amazon Soil Till Res 103:342-349

Craine JME AJW, L.; Augusto, L.; Baisden, W. T.; Brookshire, E. N.; Cramer, M. D.; Hasselquist, N. J.; Hobbie, E. A.; Kahmen, A.; Koba, K.; Kranabetter, J. M.; Mack, M. C.; Marin-Spiotta, E.; Mayor, J. R.; McLauchlan, K. K.; Michelsen, A.; Nardoto, G. B.; Oliveira, R. S.; Perakis, S. S.; Peri, P. L.; Quesada, C. A.; Richter, A.; Schipper, L. A.; Stevenson, B. A.; Turner, B. L.; Viani, R. A.; Wanek, W.; Zeller, B. (2015) Convergence 
of soil nitrogen isotopes across global climate gradients Sci Rep 5:8280 doi:10.1038/srepo8280

Cruvinel ÊBF, Bustamante MMC, Kozovits ARK, Zepp RG (2011) Soil emissions of NO, N2O and $\mathrm{CO}_{2}$ from croplands in the savanna region of central Brazil Agric Ecosyst Environ 144:29-40 doi:10.1016/j.agee.2011.07.016

Delwiche CC, Zinke PJ, Johnson CM, Virginia RA (1979) Nitrogen isotope distribution as a presumptive indicator of nitrogen fixation Botanical Gazette doi:10.2307/2474205

Embrapa (1999) Manual de análises químicas de solos, plantas e fertilizantes. Embrapa, Brasília

Embrapa (2006) Sistema brasileiro de classificação de solos. 2nd edn. Embrapa - SPI, Rio de Janeiro

Erguder TH, Boon N, Wittebolle L, Marzorati M, Verstraete W (2009) Environmental factors shaping the ecological niches of ammonia-oxidizing archaea FEMS microbiology reviews 33:855-869 doi:10.1111/j.1574-6976.2009.00179.x

Gubry-Rangin C et al. (2011) Niche specialization of terrestrial archaeal ammonia oxidizers PNAS 108:21206-21211 doi:10.1073/pnas.1109000108

Gubry-Rangin C, Nicol GW, Prosser JI (2010) Archaea rather than bacteria control nitrification in two agricultural acidic soils FEMS Microbiol Ecol 74:566-574 doi:10.1111/j.1574-6941.2010.00971.x

Hammer O, Harper DAT, Ryan PD (2001) PAST: Paleontological Statistics software package for education and data analysis Palaeontologica Eletronica 4:9

Hernández-Hernández RM, López-Hernández D (2002) Microbial biomass, mineral nitrogen and carbon content in savanna soil aggregates under conventional and no-tillage Soil Biol Biochem 34:1563-1570

Isobe KK, K.; Suwa, Y.; Ikutani, J.; Fang, Y.; Yoh, M.; Mo, J.; Otsuka, S.; Senoo, K. (2012) High abundance of ammonia-oxidizing archaea in acidified subtropical forest soils in southern China after long-term N deposition FEMS Microbiol Ecol 80:193-203 doi:10.1111/j.1574-6941.2011.01294.x

Jangid K, Williams MA, Franzluebbers AJ, Schmidt TM, Coleman DC, Whitman WB (2011) Land-use history has a stronger impact on soil microbial community composition 
than aboveground vegetation and soil properties Soil Biol Biochem 43

Jia Z, Conrad R (2009) Bacteria rather than Archaea dominate microbial ammonia oxidation in an agricultural soil Environ Microbiol 11:1658-1671 doi:10.1111/j.14622920.2009.01891.x

Lazcano C, Gómez-Brandón M, Revilla P, Domínguez J (2013) Short-term effects of organic and inorganic fertilizers on soil microbial community structure and function Biol Fert Soils 49:723-733

Leininger SU, T.; Schloter, M.; Schwark, L.; Qi, J.; Nicol, G.; Prosser, J.; Schuster, S.; Schleper, C. (2006) Archaea predominate among ammonia-oxidizing prokaryotes in soils Nature 442:806-809 doi:10.1038/nature04983

Levičnik-Höfferle S, Nicol GW, Ausec L, Mandić-Mulec I, Prosser JI (2012) Stimulation of thaumarchaeal ammonia oxidation by ammonia derived from organic nitrogen but not added inorganic nitrogen FEMS Microbiol Ecol 80:114-123 doi:10.1111/j.15746941.2011.01275.x

Mao Y, Yannarell AC, Mackie RI (2011) Changes in N-transforming archaea and bacteria in soil during the establishment of bioenergy crops PLoS One 6:e24750 doi:10.1371/journal.pone.0024750

Martens-Habbena W, Berube PM, Urakawa H, de la Torre JR, Stahl DA (2009) Ammonia oxidation kinetics determine niche separation of nitrifying Archaea and Bacteria Nature 461:976-979 doi:10.1038/natureo8465

Meier M (1991) Nitratbestimmung in Boden-Proben (N-min-Methode) LaborPraxis, Würzburg: 244-247

Mendes IC, Hungria M, Vargas MAT (2003) Soybean response to starter nitrogen and Bradyrhizobium inoculation on a Cerrado Oxisol under no-tillage and conventional 
tillage systems Revista Brasileira de Ciência do Solo 27:81-87 doi:10.1590/S010006832003000100009

Mendes LWK, E. E.; Navarrete, A. A. ; van Veen, J. A.; Tsai, S. M. (2014) Taxonomical and functional microbial community selection in soybean rhizosphere The ISME Journal 8:1577-1587 doi:10.1038/ismej.2014.17

Meyer A, Focks A, Radl V, Welzl G, Schöning I, Schloter M (2014) Influence of land use intensity on the diversity of ammonia oxidizing bacteria and archaea in soils from grassland ecosystems Microbial Ecol 67:161-166 doi:10.1007/s00248-013-0310-4

Mulvaney RL (1996) Nitrogen inorganic forms. In: Sparks DL (ed) Methods of soil analyses, vol 3. Soil Science Society of America, Madison, pp 1123-1184

Nardoto GB, Bustamante MMC (2003) Effects of fire on soil nitrogen dynamics and microbial biomass in savannas of Central Brazil Pesquisa Agropecuária Brasileira 38:955-962

Nicol GW, Leininger S, Schleper C, Prosser JI (2008) The influence of soil pH on the diversity, abundance and transcriptional activity of ammonia oxidizing archaea and bacteria Environ Microbiol 10:2966-2978 doi:10.1111/j.1462-2920.2008.01701.x

Ochsenreiter T, Selezi D, Quaiser A, Bonch-Osmolovskaya L, Schleper C (2003) Diversity and abundance of Crenarchaeota in terrestrial habitats studied by 16S RNA surveys and real time PCR Environ Microbiol 5:787-797

Paula FR, JL; Zhou, J; Wu, L; Mueller, RC; Mirza, BS; Bohannan, BJ; Nusslein, K; Deng, Y; Tiedje, JM; Pellizari, VH (2014) Land use change alters functional gene diversity, composition and abundance in Amazon forest soil microbial communities Mol Ecol 23:2988-2999 doi:10.1111/mec.12786

Peixoto RS, Chaer GM, Franco N, Reis Junior FB, Mendes IC, Rosado AS (2010) A decade of land use contributes to changes in the chemistry, biochemistry and bacterial community structures of soils in the Cerrado Antonie Van Leeuwenhoek 98:403-413 doi:10.1007/s10482-010-9454-0

Piccolo MC, Neill C, Cerri CC (1994) Net nitrogen mineralization and net nitrification along a tropical forest-to-pasture chronosequence Plant Soil 162:61-70 doi:10.1007/BF01416090

Pinto AS, Bustamante MMC, Kisselle K, Burke R, Zepp R, Viana LT, Varella RFM, M. (2002) Soil emissions of $\mathrm{N} 2 \mathrm{O}, \mathrm{NO}$, and $\mathrm{CO} 2$ in Brazilian Savannas: Effects of vegetation 
type, seasonality, and prescribed fires J Geophys Res 107:1-9

doi:10.1029/2001JD000342

Pinto ASB, M.M.C.; da Silva, M. R. S. S.;Kisselle, K. W.;Brossard, M.;Kruger, R.;Zepp, R.

G.;Burke, R. A. (2006) Effects of Different Treatments of Pasture Restoration on Soil Trace Gas Emissions in the Cerrados of Central Brazil Earth Interact 10:1-26

Placella SA, Firestone MK (2013) Transcriptional response of nitrifying communities to wetting of dry soil Appl Environ Microbiol 79:3294-3302 doi:10.1128/AEM.00404-13

Prosser J, Nicol G (2012) Archaeal and bacterial ammonia-oxidisers in soil: the quest for niche specialisation and differentiation Trends Microbiol 20:523-531 doi:10.1016/j.tim.2012.08.001

Rachid CTS, A. L.; Piccolo, M. C.; Balieiro, F. C.; Coutinho, H. L.; Peixoto, R. S.; Tiedje, J. M.; Rosado, A. S. (2013) Effect of sugarcane burning or green harvest methods on the Brazilian Cerrado soil bacterial community structure PLoS One 8:e59342 doi:10.1371/journal.pone.0059342

Ribeiro JFW, B.M.T. (2008) As principais fitofisionomias do Bioma Cerrado. In: Sano SMA, S.P.; Ribeiro, J.F. (ed) Cerrado: ecologia e flora. Embrapa Cerrados Planaltina, pp 151212

Rice WR (1989) Analyzing Tables of Statistical Tests Evolution 43:223-225 doi:Doi $10.2307 / 2409177$

Rotthauwe JH, Witzel KP, Liesack W (1997) The ammonia monooxygenase structural gene amoA as a functional marker: molecular fine-scale analysis of natural ammoniaoxidizing populations Appl Environ Microbiol 63:4704-4712

Souza RCC, M.E.; Vasconcelos,A.T.R.; Nogueira, M.A.; Hungria,M. (2013) Soil metagenomics reveals differences under conventional and no-tillage with crop rotation or succession Appl Soil Ecol 72 doi:10.1016/j.apsoil.2013.05.021

Stephen JR, Kowalchuk GA, Bruns MAV, McCaig AE, Phillips CJ, Embley TM, Prosser J (1998) Analysis of beta-subgroup proteobacterial ammonia oxidizer populations in soil by denaturing gradient gel electrophoresis analysis and hierarchical phylogenetic probing Appl Environ Microbiol 64:2958-2965

Stopnisek NG-R, C.; Hofferle, S.; Nicol, G. W.; Mandic-Mulec, I.; Prosser, J. I. (2010)

Thaumarchaeal Ammonia Oxidation in an Acidic Forest Peat Soil Is Not Influenced 
by Ammonium Amendment Appl Environ Microbiol 76:7626-7634 doi:Doi 10.1128/Aem.00595-10

Thion C, Prosser Jl (2014) Differential response of nonadapted ammonia-oxidising archaea and bacteria to drying-rewetting stress FEMS Microbiol Ecol 90:380-389 doi:10.1111/1574-6941.12395

Tourna MF, T. E.; Nicol, G. W.; Prosser, J. I. (2008) Growth, activity and temperature responses of ammonia-oxidizing archaea and bacteria in soil microcosms Environ Microbiol 10:1357-1364 doi:10.1111/j.1462-2920.2007.01563.x

Vinhal-Freitas IC, Ferreira AS, Corrêa GF, Wendling B (2012) Land Use Impact on Microbial and Biochemical Indicators in Agroecosystems of the Brazilian Cerrado Vadose Zone J 12:1-8

Weber EB, Lehtovirta-Morley LE, Prosser Jl, Gubry-Rangin C (2015) Ammonia oxidation is not required for growth of Group 1.1C soil Thaumarchaeota FEMS Microbiol Ecol 91 doi:10.1093/femsec/fivoo1

Wertz S, Leigh AKK, Grayston SJ (2012) Effects of long-term fertilization of forest soils on potential nitrification and on the abundance and community structure of ammonia oxidizers and nitrite oxidizers FEMS Microbiol Ecol 79:142-154 doi:10.1111/j.1574$6941.2011 .01204 \cdot x$

Yu Z, Zhang Y, Luo W, Wang Y (2014) Root colonization and effect of biocontrol fungus Paecilomyces lilacinus on composition of ammonia-oxidizing bacteria, ammonia oxidizing archaea and fungal populations of tomato rhizosphere Biol Fert Soils 51:343-351 doi:doi:10.1007/s00374-014-0983-y

Zhang LM, W. HH, P. SJ, Z. HJ (2012) Ammonia-oxidizing archaea have more important role than ammonia-oxidizing bacteria in ammonia oxidation of strongly acidic soils ISME J 6:1032-1045 doi:doi:10.1038/ismej.2011.168 
Figure 1. Principal component analysis (PCA) of soil physicochemical properties based on a correlation matrix performed in PAST v.3.01 (Hammer et al. 2001). (A) Analysis of soybean site samples; (B) all samples including soil from the undisturbed Campo sujo site. Each vector points in the direction in which the respective value increases.

Figure 2. One-way ANOVA tests on soil N values, with Tukey-Kramer post hoc tests to compare group means ( $\mathrm{R}$ with the ggplot2 package). Concentrations of (A) $\mathrm{NH}_{4}{ }^{+}-\mathrm{N}$ and (B) $\mathrm{NO}_{3}^{-}-\mathrm{N}$ in soil samples under each condition. (C) Net mineralization and (D) nitrification (D) determined by inorganic nitrogen $\underline{\mathrm{N} \text { and }} \mathrm{NO}_{3}{ }^{-}-\mathrm{N}$ content, respectively, measured after soil incubation in the laboratory for 1 week; (D) $\mathrm{NH}_{4}{ }^{+}-\mathrm{N}$ : $\mathrm{NO}_{3}-\mathrm{N}$ ratio and (F) integrated values of soil $\delta^{15} \mathrm{~N}(\%)$. Letters represent significant differences in inorganic $\mathrm{N}$ content between soil samples after post hoc tests: upper case letters represent difference between undisturbed Campo sujo and fallow soil from the soybean site; lower case letters present differences among soybean site samples. Soil samples obtained during the blossom stage of soybean development are represented by Blossom-B for bulk soil and Blossom-R for rhizosphere soil.

Figure 3. Changes in (A) AOA amoA gene abundance, (B) AOB $a m o A$ gene abundance, (C) AOA:AOB amoA gene abundance ratio, and (D) archaeal 16S rRNA:amoA gene abundance ratio. One-way ANOVA tests were performed, followed by Tukey-Kramer post hoc tests to compare group means ( $\mathrm{R}$ package with the ggplot2 library). Different letters represent significant differences in gene abundance after post hoc tests: upper case letters represent difference between undisturbed Campo sujo and fallow soil from the soybean site; lower case letters present differences among soybean site samples. Soil samples obtained during the blossom stage of soybean development are represented by Blossom-B for bulk soil and Blossom-R for rhizosphere soil.

Figure S1. Gravimetric soil water content. Boxplot created by R version 3.0.2 with the ggplot2 library. Letters and corresponding colors correspond to significant differences among groups after the Tukey-Kramer post hoc test.

Figure S2. Satellite view and photographs of the sample site on the Tabapuã dos Pireneus Farm. (A) Schematic representation of the sampling design on a Google Earth picture from the sample site. 1-3 represent composite samples for molecular analysis. (B)-(F) Photos of the soil collection sites. (B) Undisturbed Campo sujo site, (C)-(F) Soybean site at four different time points: (C) after 
9 months of natural fallow, (D) 1 month after fertilization, (E) during the blossom stage of soybean development, $(\mathrm{F})$ soybean plants with beans.

Figure S3. Relationship between soil $\delta^{13} \mathrm{C}$ and $\delta^{15} \mathrm{~N}$ in \%o. Each point represents samples from each soil condition, marked with different symbols. 
Table 1. Soil physicochemical properties for each one of the replicates in all treatments. AT: average temperature; SWC: Soil water content; CEC: cation exchange capacity; DS: dry soil; OM: organic matter.

\begin{tabular}{|c|c|c|c|c|c|}
\hline & Campo sujo & Fallow & Tilled & Fertilized & Bulk - Blossom \\
\hline $\operatorname{SWC}\left(\% \mathrm{H} 20 \mathrm{~g}^{-1} \mathrm{DS}\right)$ & $16.1 \pm 0.9$ & $21.7 \pm 2.063$ & $22.9 \pm 1.873$ & $26.3 \pm 1.583$ & $19.8 \pm 1.675$ \\
\hline Clay $\left(\mathrm{g} \mathrm{kg}^{-1}\right)$ & $208.3 \pm 8.3$ & $308.3 \pm 8.333$ & $325.0 \pm 14.434$ & $333.3 \pm 8.333$ & $300.0 \pm 14.434$ \\
\hline Sand $\left(\mathrm{g} \mathrm{kg}^{-1}\right)$ & $733.3 \pm 8.3$ & $600.0 \pm 14.434$ & $541.7 \pm 8.333$ & $550.0 \pm 14.434$ & $558.3 \pm 16.667$ \\
\hline Silt $\left(\mathrm{g} \mathrm{kg}^{-1}\right)$ & $58.3 \pm 8.3$ & $91.7 \pm 8.333$ & $133.3 \pm 16.667$ & $116.7 \pm 8.333$ & $141.7 \pm 8.333$ \\
\hline $\mathrm{pH}\left(\mathrm{em} \mathrm{H}_{2} \mathrm{O}\right)$ & $5.4 \pm 0.1$ & $5.5 \pm 0.058$ & $6.0 \pm 0.033$ & $6.0 \pm 0.033$ & $6.0 \pm 0.058$ \\
\hline $\mathrm{pH}(\mathrm{em} \mathrm{KCl})$ & $3.6 \pm 0.1$ & $4.3 \pm 0.100$ & $5.2 \pm 0.033$ & $5.2 \pm 0.058$ & $5.0 \pm 0.058$ \\
\hline CEC (cmolc dm-3) & $6.0 \pm 0.6$ & $6.0 \pm 0.577$ & $6.3 \pm 0.333$ & $6.7 \pm 0.333$ & $6.7 \pm 0.333$ \\
\hline $\mathrm{Al}$ (cmolc dm-3) & $1.2 \pm 0.1$ & $0.1 \pm 0.033$ & $0.0 \pm 0.000$ & $0.0 \pm 0.000$ & $0.0 \pm 0.000$ \\
\hline $\mathrm{N}(\%)$ & $0.11 \pm 0.00$ & $0.12 \pm 0.01$ & $0.12 \pm 0.01$ & $0.12 \pm 0.00$ & $0.10 \pm 0.00$ \\
\hline$\delta^{15} \mathrm{~N}$ & $5.64 \pm 0.08$ & $7.05 \pm 0.12$ & $7.15 \pm 0.16$ & $7.16 \pm 0.10$ & $7.57 \pm 0.14$ \\
\hline $\mathrm{C}(\%)$ & $1.76 \pm 0.03$ & $2.04 \pm 0.16$ & $1.99 \pm 0.12$ & $1.92 \pm 0.10$ & $1.63 \pm 0.06$ \\
\hline $\mathrm{OM}(\mathrm{g} \mathrm{kg}-1)$ & $42.6 \pm 2.4$ & $45.0 \pm 4.159$ & $39.1 \pm 1.258$ & $38.1 \pm 2.118$ & $36.5 \pm 2.586$ \\
\hline $\mathrm{P}(\mathrm{mg} \mathrm{dm}-3)$ & $1.8 \pm 0.1$ & $1.2 \pm 0.418$ & $14.6 \pm 6.053$ & $14.1 \pm 1.510$ & $20.9 \pm 11.767$ \\
\hline $\mathrm{Ca}(\mathrm{cmolc} \mathrm{dm}-3)$ & $0.4 \pm 0.06$ & $0.7 \pm 0.115$ & $2.7 \pm 0.067$ & $2.7 \pm 0.338$ & $2.7 \pm 0.088$ \\
\hline $\operatorname{Mg}(\mathrm{cmolc}$ dm-3) & $0.1 \pm 0.03$ & $0.6 \pm 0.145$ & $0.8 \pm 0.033$ & $0.7 \pm 0.120$ & $0.8 \pm 0.033$ \\
\hline B (mg dm-3) & $0.24 \pm 0.04$ & $0.10 \pm 0.039$ & $0.46 \pm 0.012$ & $0.49 \pm 0.040$ & $0.48 \pm 0.026$ \\
\hline $\mathrm{Cu}(\mathrm{mg} \mathrm{dm}-3)$ & $1.72 \pm 0.04$ & $1.57 \pm 0.113$ & $0.06 \pm 0.020$ & $0.05 \pm 0.012$ & $0.05 \pm 0.028$ \\
\hline $\mathrm{Fe}(\mathrm{mg} \mathrm{dm}-3)$ & $165.40 \pm 41.01$ & $86.03 \pm 6.731$ & $106.40 \pm 4.277$ & $141.00 \pm 7.000$ & $92.37 \pm 29.453$ \\
\hline $\operatorname{Mn}(\mathrm{mg} \mathrm{dm}-3)$ & $68.74 \pm 58.82$ & $9.01 \pm 2.865$ & $7.70 \pm 0.141$ & $7.43 \pm 1.017$ & $8.64 \pm 0.380$ \\
\hline $\mathrm{Zn}(\mathrm{mg} \mathrm{dm}-3)$ & $1.75 \pm 1.71$ & $0.22 \pm 0.101$ & $1.65 \pm 0.405$ & $2.34 \pm 0.418$ & $3.54 \pm 1.033$ \\
\hline $\mathrm{S}(\mathrm{mg} \mathrm{dm}-3)$ & $6.03 \pm 0.15$ & $3.20 \pm 0.100$ & $3.13 \pm 0.145$ & $4.13 \pm 0.865$ & $4.63 \pm 0.835$ \\
\hline
\end{tabular}


Figure 1

1
2
3
4
$A_{6}^{5}$

7
8

8

10

11

1요

集

$\triangle B$

21

22

23

24

25

26

27

28
29

30

31

32

33

35

36

37

38

39

40

41

42

4

4

45

整

80

.

5

5

52

53

54

55

56

57

58

59

60

61

62

63

64

65
- Fertilized

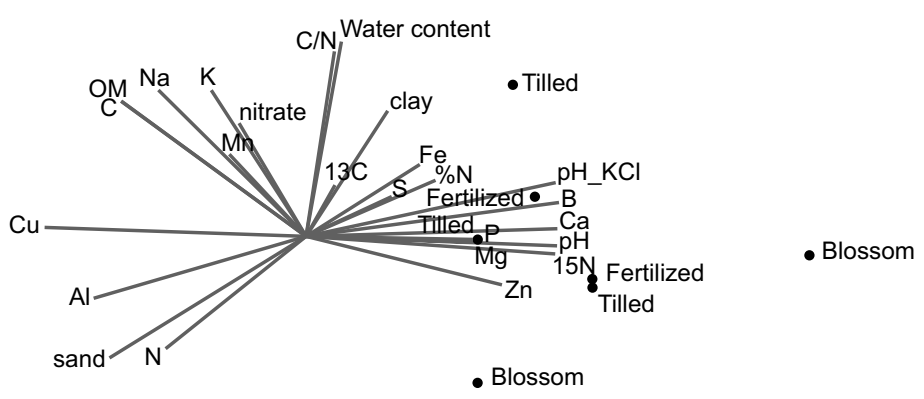

- Fallow

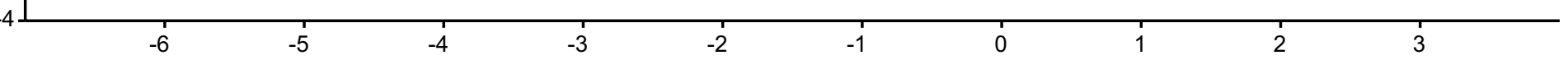

Component 1 (41.7\%)

-Fallow

- Fallow

Fallow

- Campo sujo
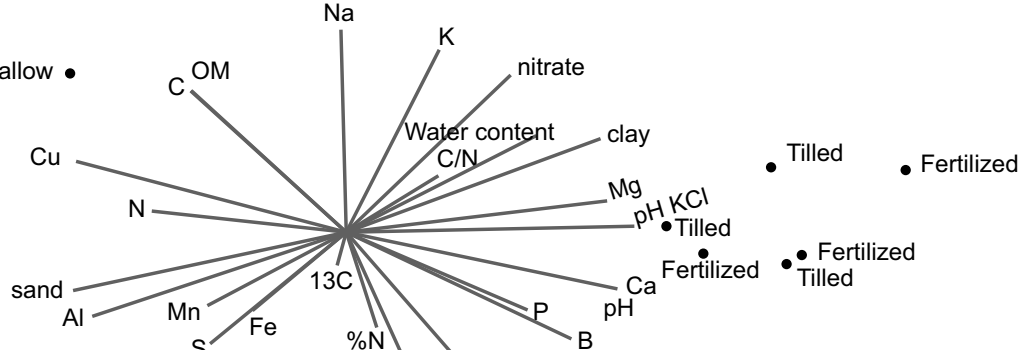

Tilled

- Blossom

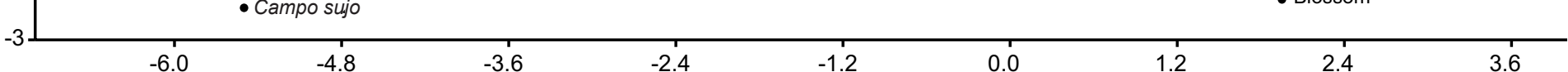

Component 1 (42.0\%) 
Figure 2
$A^{50-}$

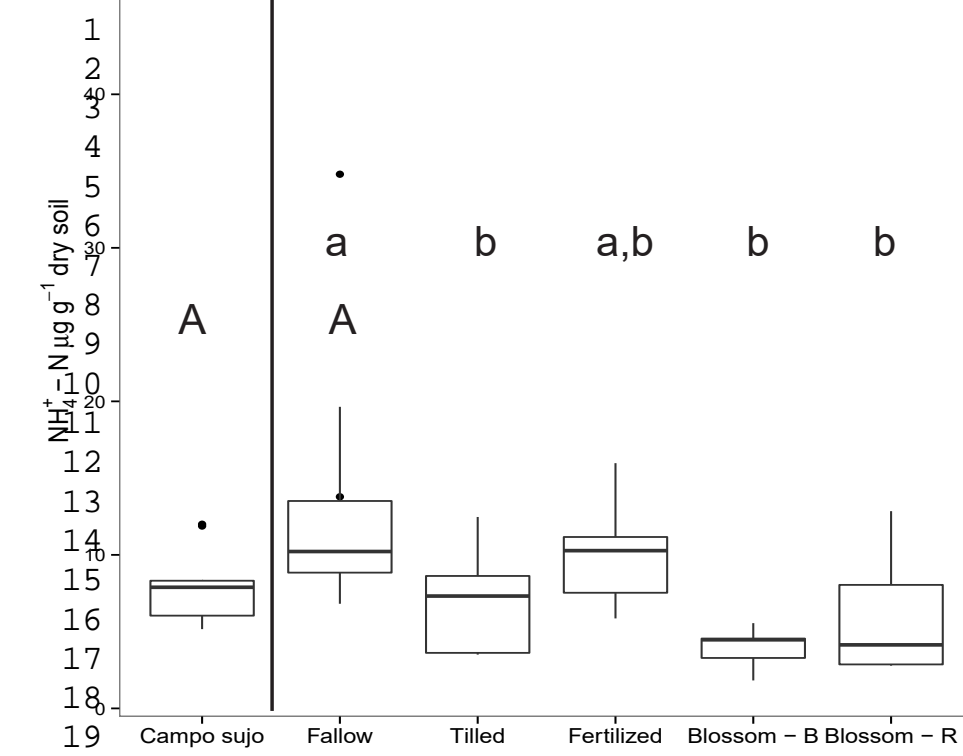
20 $\mathrm{C}_{2}$ 23 일 要 5 $26^{2}$ 응 38 , 29 $\$ 30$ 虽1

$+32$

$\sqrt{3} 3^{0}$ .34

番5 㩊6

$4 \bar{\Theta}^{2}$

41

42

$\mathrm{E}^{4}$

E

4

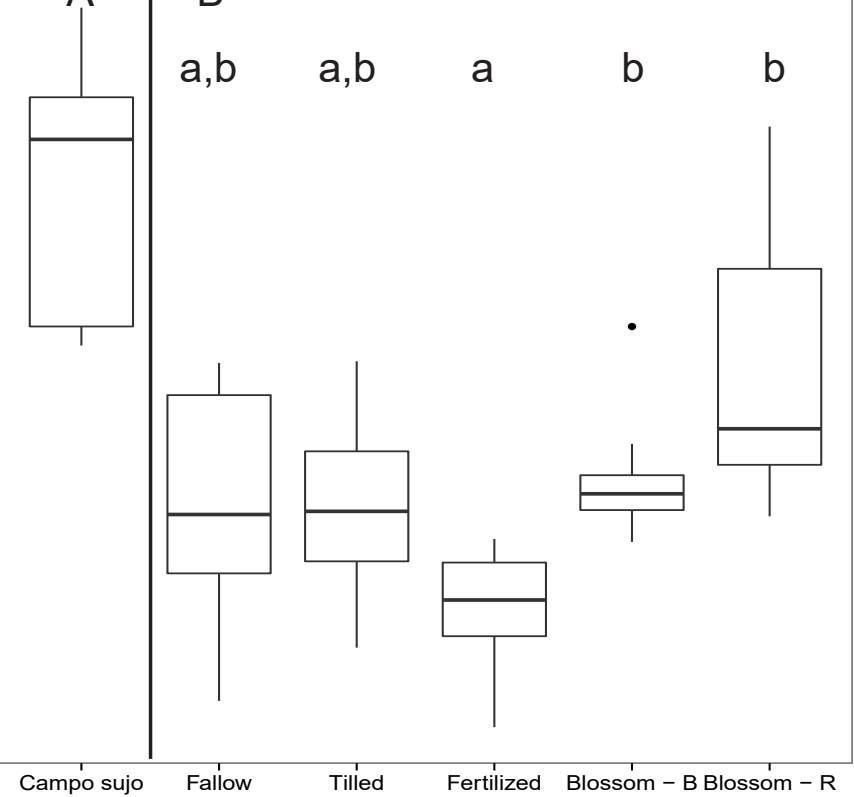

Campo sujo Fallow $\quad$ Tilled $\quad$ Fertilized Blossom - B Blossom - R

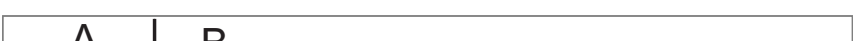

A
$\mathrm{B}$

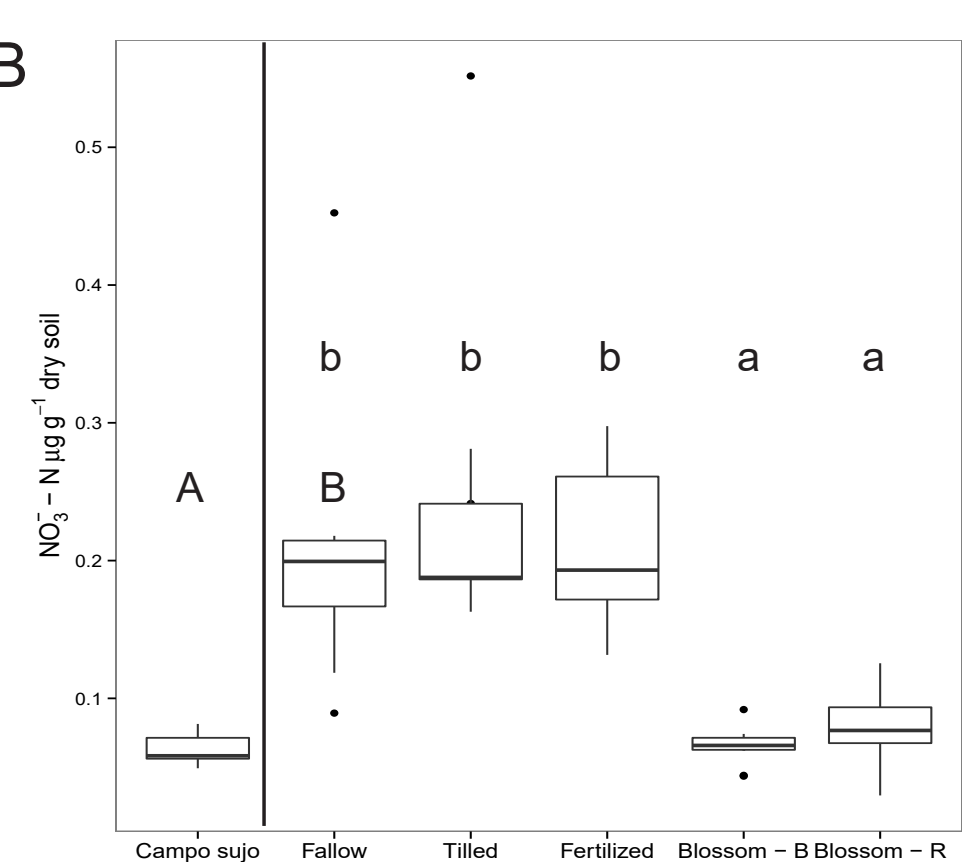

D

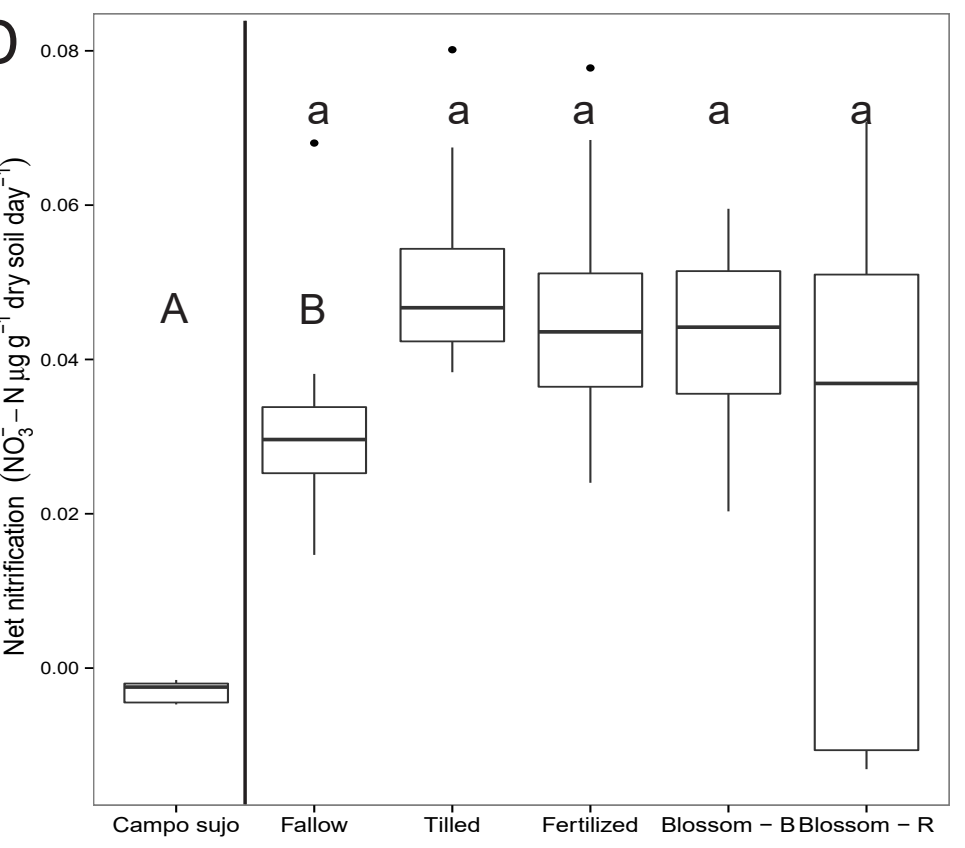

F

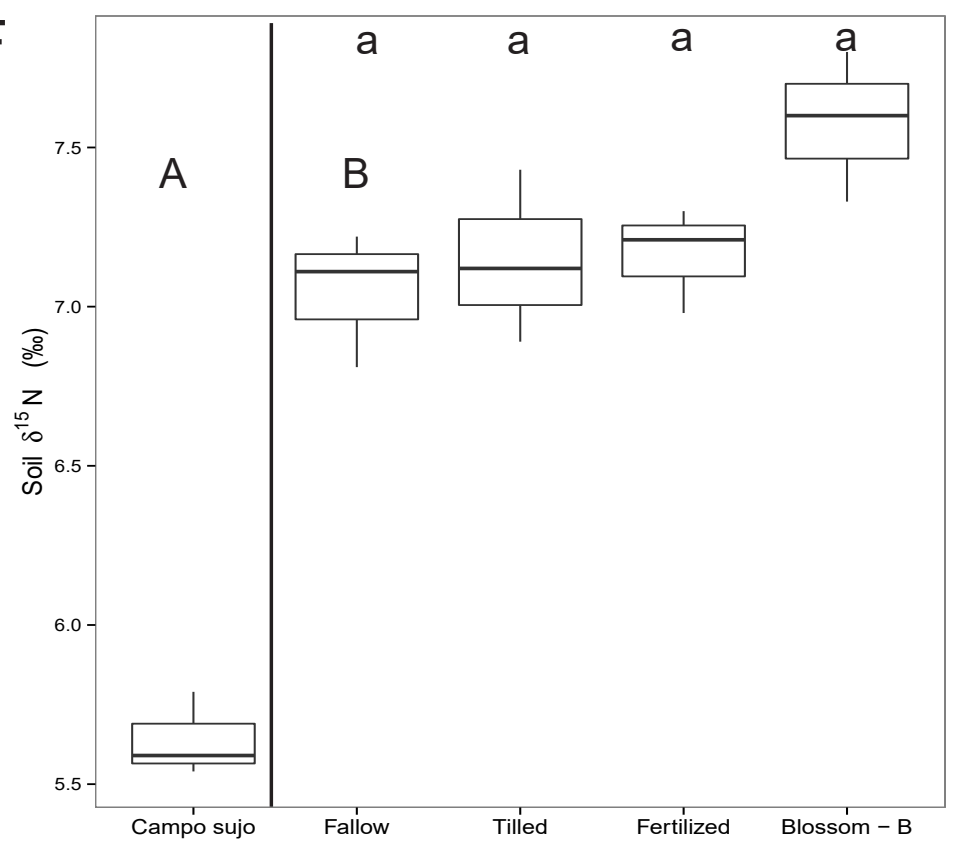


Figure 3

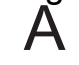

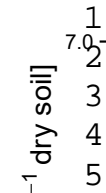

'๐ 5

\& 7

당 6.5

క 9

ब 10

$\stackrel{\oplus}{\Phi} 11$

\$12

13

है 1.4

ธ 15

$\leq 16$

웅 17

19

20

21

22

23

24

$\mathrm{C}_{26}^{25}$

임 27

29

중 30

일 31

을 232

\& 33

34

35

ㅇ 36

๙ 37

$\varangle 38$

239

$\div 41$

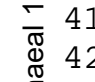

든 43

$\leq 44$

웅 45

2.46

47

48

49

51

52

53

54

55

56

57

58

59

60

61

62

63

64

65
A B
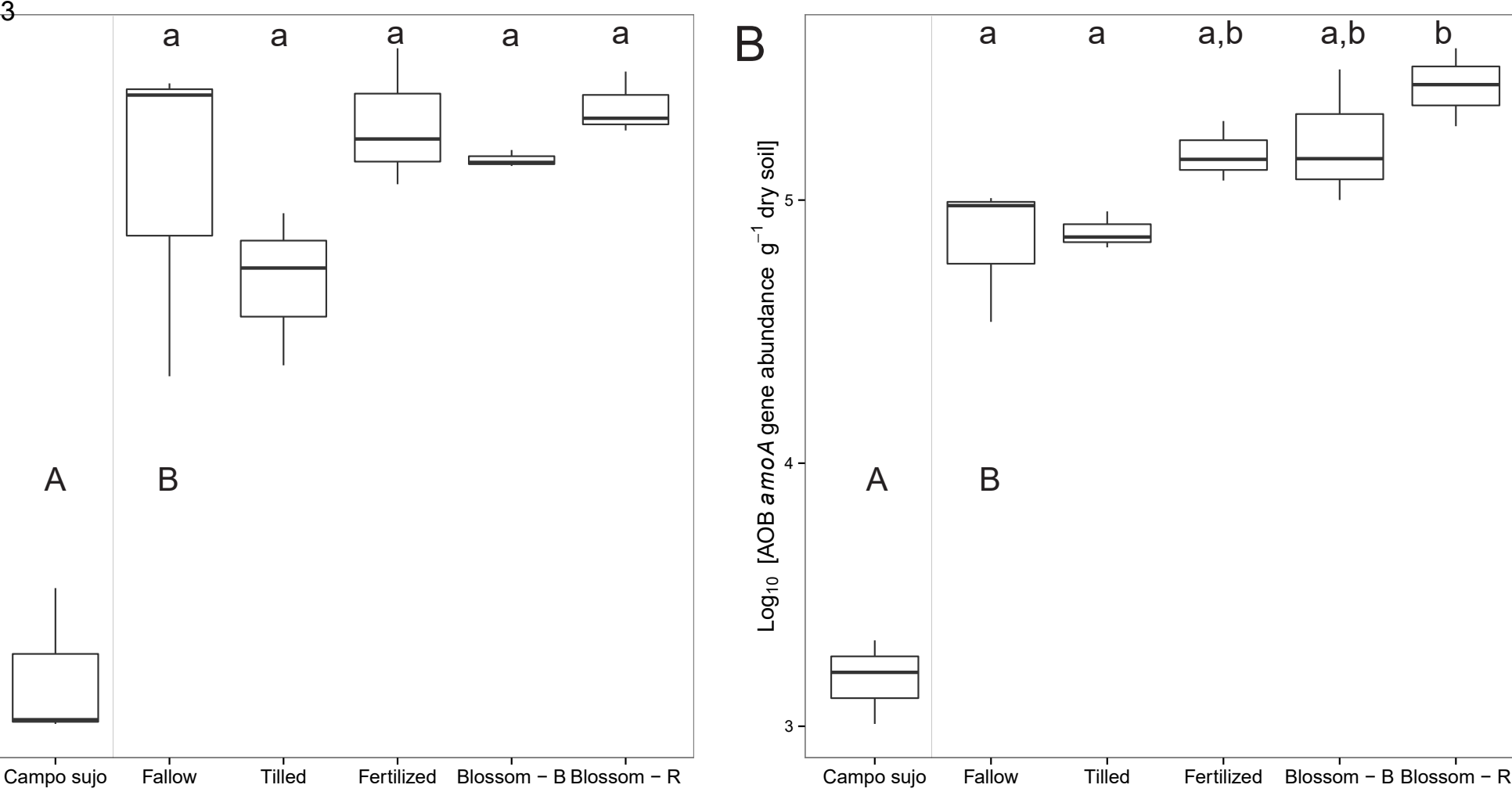

A B

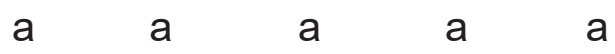

Campo sujo Fallow Tilled Fertilized Blossom-B Blossom - R
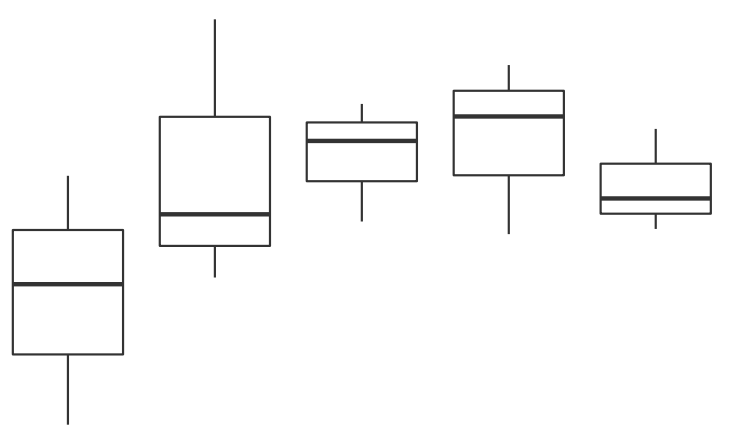

$3-$
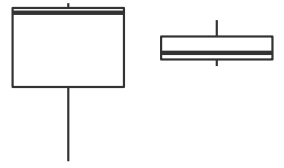

A

B

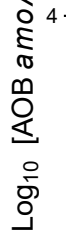
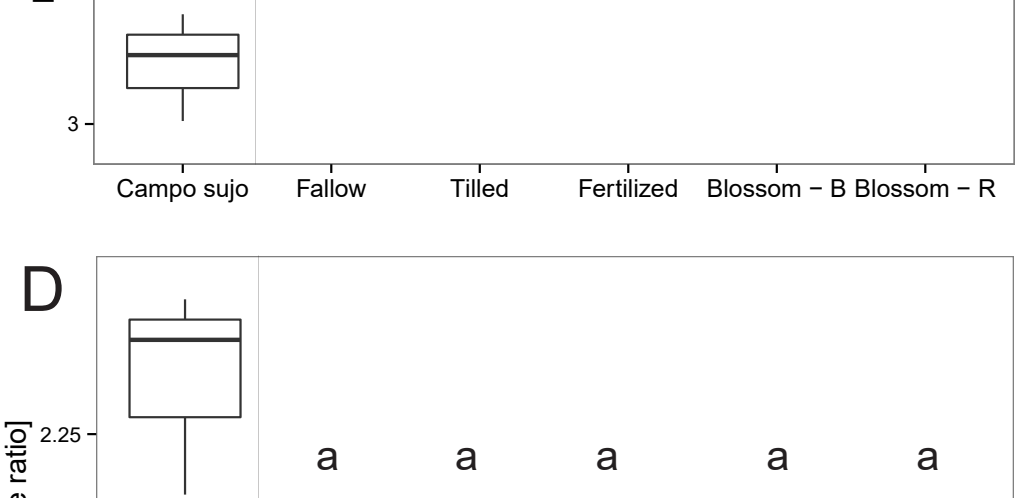

a

a

a

a

a
A
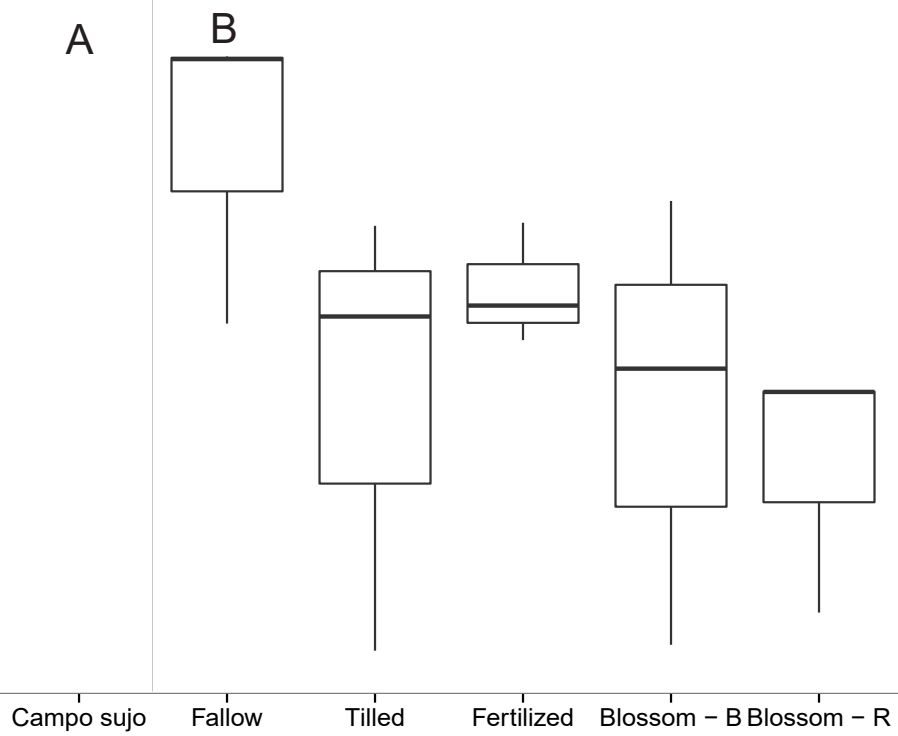
Figure S1

1

2

3

4

5

6

8

9

10

11

12

13

14

15

16

17

18

19

20

21

22

23

24

25

26

27

28

29

30

31

32

33

34

35

36

37

38

39

40

41

42

43

44

45

46

47

48

49

50

51

52

53

54

55

56

57

58

59

60

61

62

63

64

65
A

a

$\frac{3}{3}$

$\underbrace{2} 30-$

$\frac{1}{0}$
$\stackrel{0}{0}$
0
$\frac{\overline{0}}{0}$
$\frac{1}{ \pm}$
$\frac{1}{3}$

$20-$

Campo sujo

Tilled

a

a

a

a

B
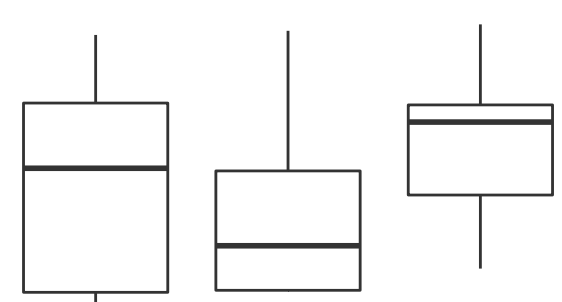

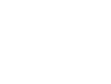

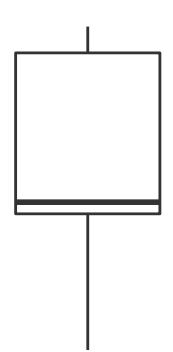

Fertilized

Blossom - B Blossom - R

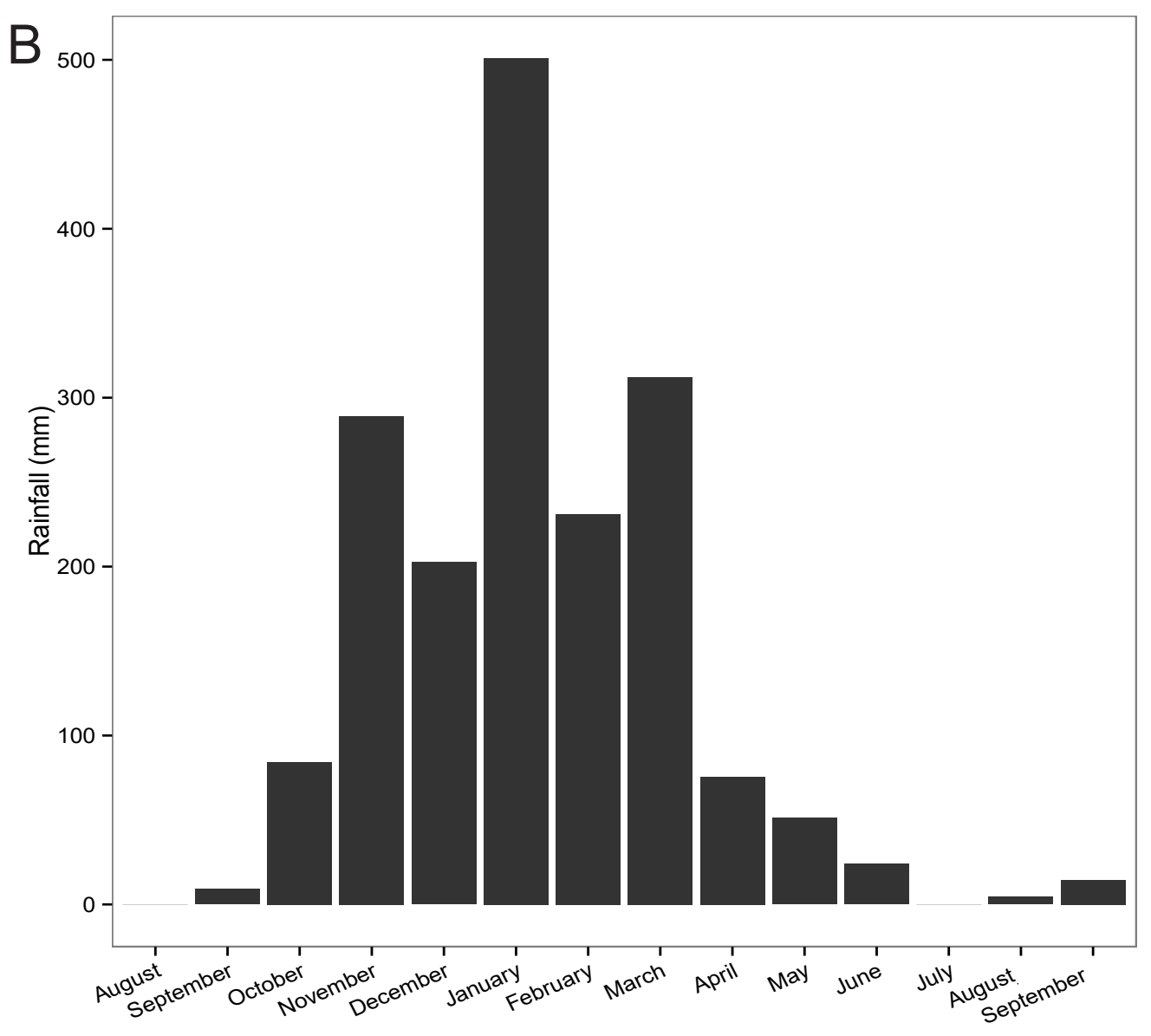



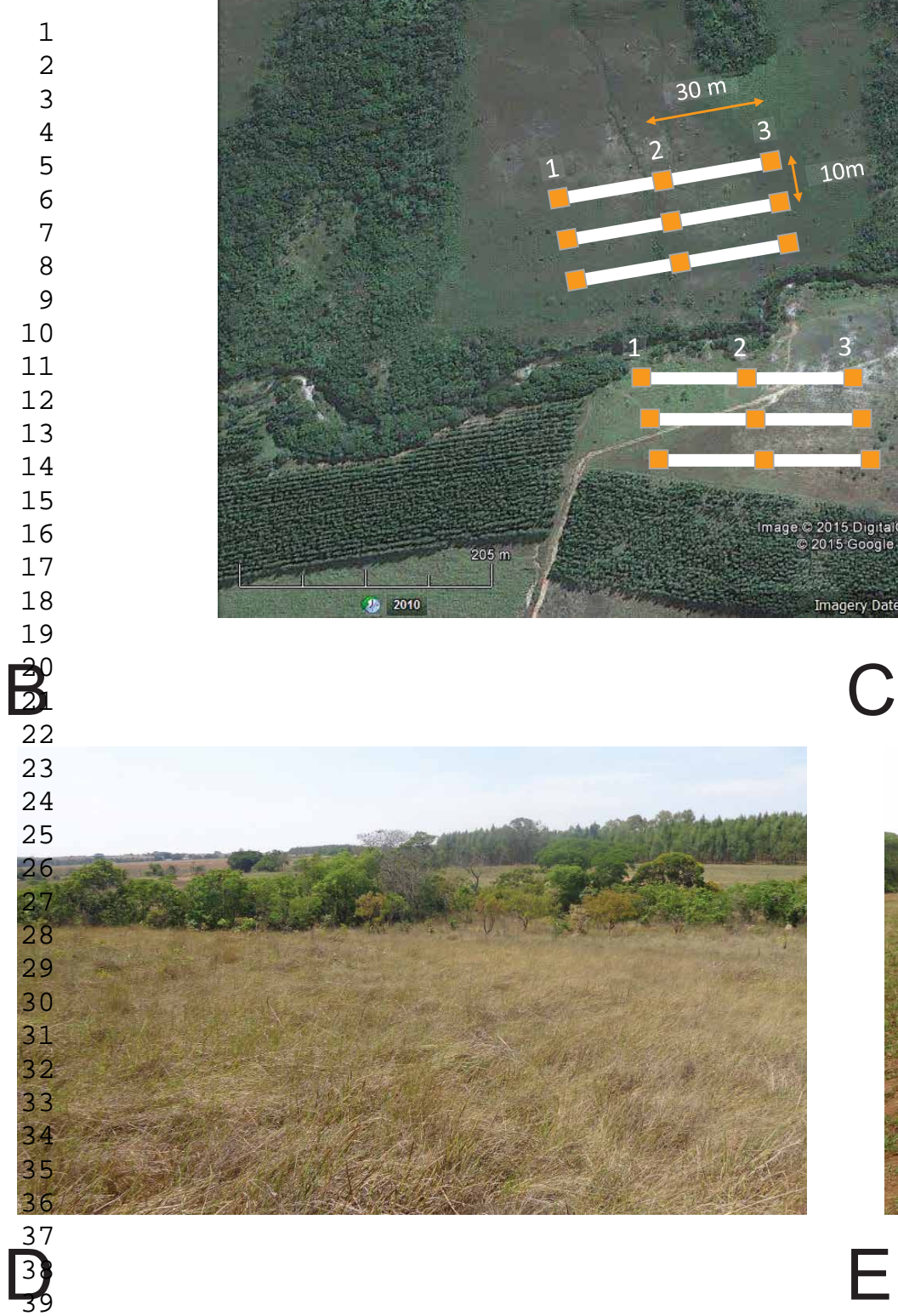

42

43

44

45

46

47

48
49
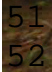

C
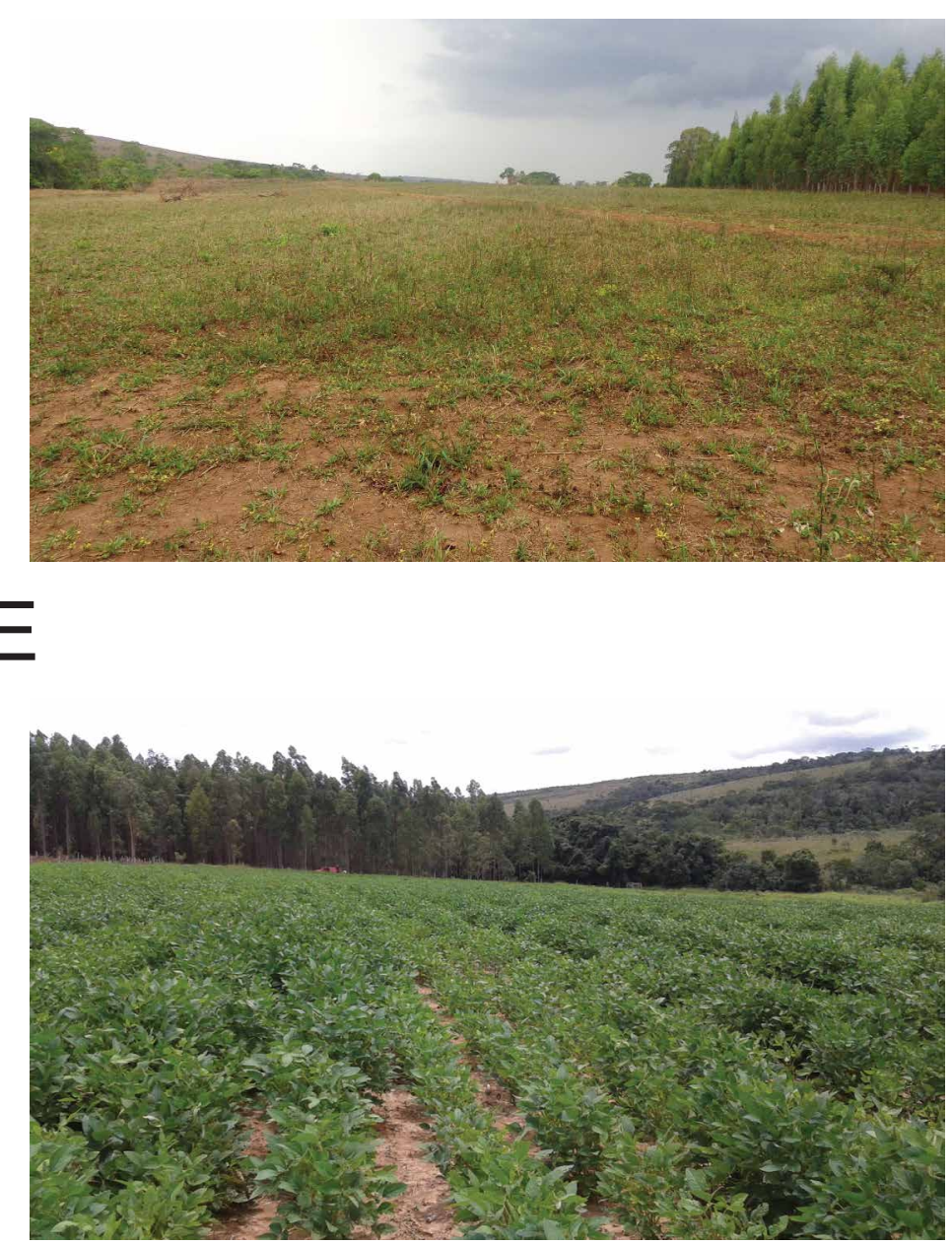

$E$

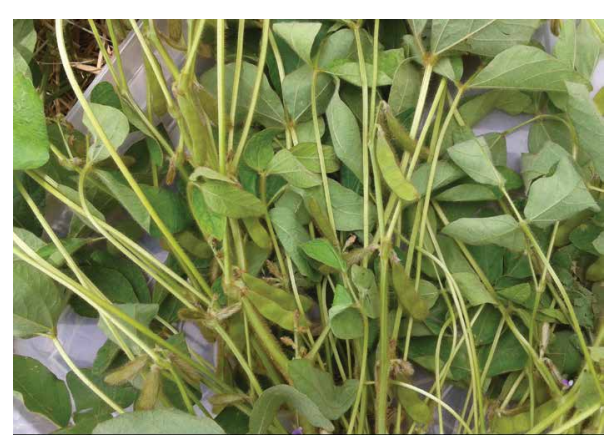


Figure S3

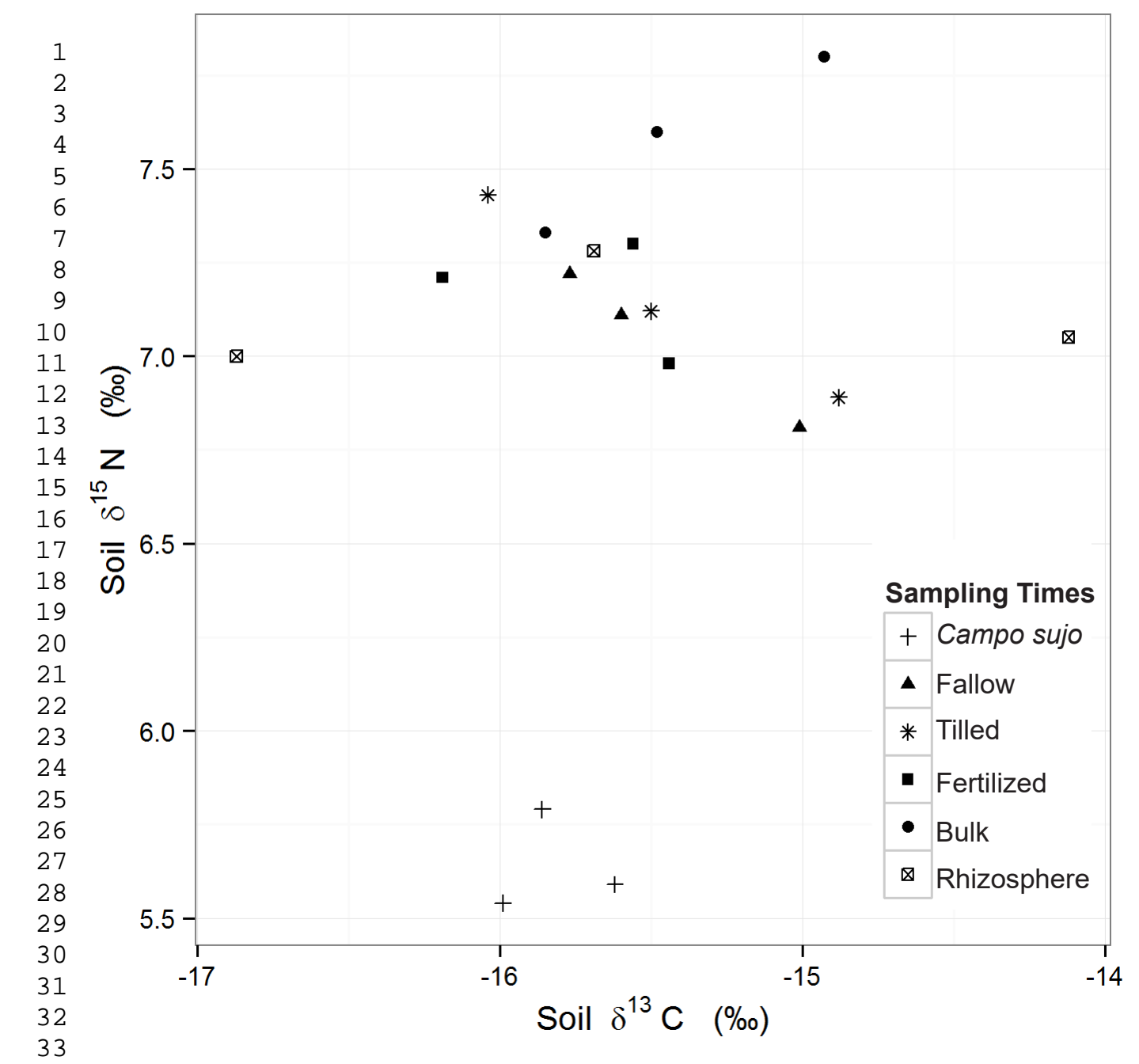

34

35

36

37

38

39

40

41

42

43

44

45

46

47

48

49

50

51

52

53

54

55

56

57

58

59

60

61

62

63

64

65 